NBER WORKING PAPER SERIES

\title{
CROSS-BORDER TRADING AS A MECHANISM FOR CAPITAL FLIGHT: ADRs AND THE ARGENTINE CRISIS
}

\author{
Sebastian Auguste \\ Kathryn M.E. Dominguez \\ Herman Kamil \\ Linda L. Tesar \\ Working Paper 9343 \\ http://www.nber.org/papers/w9343

\section{NATIONAL BUREAU OF ECONOMIC RESEARCH \\ 1050 Massachusetts Avenue \\ Cambridge, MA 02138} \\ November 2002
}

\begin{abstract}
We are grateful to Ariel Burstein and Juan Carlos Hallak for planting the seed for this paper last fall. We would also like to thank seminar participants at the University of Michigan Business School Argentina Conference, Ben Chabot, Andrew Karolyi, Maria Jose Luna, Augusto Darget, and especially Juan Ignacio Gomez Vega for helping us track down data and for many helpful conversations and suggestions. The views expressed herein are those of the authors and not necessarily those of the National Bureau of Economic Research.

(C) 2002 by Sebastian Auguste, Kathryn M.E. Dominguez, Herman Kamil, and Linda L. Tesar. All rights reserved. Short sections of text, not to exceed two paragraphs, may be quoted without explicit permission provided that full credit, including (C) notice, is given to the source.
\end{abstract}


Cross-Border Trading as a Mechanism for Capital Flight: ADRs and the Argentine Crisis Sebastian Auguste, Kathryn M.E. Dominguez, Herman Kamil, and Linda L. Tesar

NBER Working Paper No. 9343

November 2002

JEL No. F32, F36, G12, G15

\section{$\underline{\text { ABSTRACT }}$}

This paper examines the surprising performance of the Argentine stock market in the midst of the country's most recent financial crisis and the role played by ADRs in Argentine capital flight. Although Argentine investors were subject to capital controls, they were able to purchase stocks with associated ADRs for pesos in Argentina, convert them into ADRs, re-sell them in New York for dollars and deposit the dollar proceeds in U.S. bank accounts. In the paper we show that: (1) ADR discounts went as high as $60 \%$ (indicating that Argentine investors were willing to pay significant amounts in order to legally move their funds abroad), (2) the market anticipated (correctly) a 40\% devaluation, (3) local market factors in Argentina became more important in pricing peso denominated stocks with associated ADRs, while the same stocks in New York were mainly priced based on global factors, (4) capital outflow using the ADR market was substantial (our estimate is between $\$ 835$ million and $\$ 3.4$ billion) .

Sebastian Auguste

University of Michigan

611 Tappan Street

Lorch Hall

Ann Arbor, MI 48109

Herman Kamil

University of Michigan

611 Tappan Street

Lorch Hall

Ann Arbor, MI 48109
Kathryn M. E. Dominguez

Ford School of Public Policy

University of Michigan

611 Tappan Street

Lorch Hall

Ann Arbor, MI 48109

and NBER

kathrynd@umich.edu

Linda Tesar

University of Michigan

611 Tappan Street

Lorch Hall

Ann Arbor, MI 48109

and NBER

ltesar@umich.edu 
"In the emerging Markets, the star performance came from Argentina. The Merval rose $25.6 \%$. This rise occurred when the country's fundamentals took a distinct turn for the worse. Draconian capital controls were introduced to preempt a massive build-up of capital flight... The reason the market is going up is simply that the stock market is seen as a way of protecting assets and a means, by ADR conversion, of getting money out of Argentina." Investavenue.com, 12-10-01.

"Buenos Aires' normally sleepy stock exchange jumped $25 \%$ in the week following Cavallo's announcement. The short-lived rally was prompted by investors who loaded up on shares in a handful of Argentine blue chips, then converted them into their corresponding American depositary receipts, sold them on the New York Stock Exchange for dollars, and parked the proceeds abroad. Since few U.S. investors want these shares, Argentines have to sell their ADRs at a loss. But apparently those in search of a safe haven for their money are willing to pay a price". Argentines Dust Off Their Survival Skills: They're using a vast array of tricks to outwit capital controls . Business Week, December 24, 2001

\section{Introduction}

This paper examines the surprising performance of the Argentine stock market in the midst of the country's most recent financial crisis and the role played by $\mathrm{ADRs}^{1}$ in Argentine capital flight. Although the exact timing and causes of Argentina's economic fall from grace are contentious, there is little disagreement that by the last quarter of 2001 Argentina was on the brink of a full-scale collapse. ${ }^{2}$ Between July and November 2001, Argentines withdrew over $\$ 15$ billion from banks -- on November 30, 2001 alone, banks saw withdrawals of \$1.3 billion. On December $3^{\text {rd }}$, in a desperate effort to prevent further massive capital outflows, financial market controls were established (these are known as the "Corralito"), which among other restrictions, imposed a ceiling of $\$ 1,000$ a month on bank withdrawals. ${ }^{3}$ In January the Argentine peso was

\footnotetext{
${ }^{1}$ American Depositary Receipts (ADRs) are shares of non-U.S. (in this case Argentine) corporations sold in the U.S (and denominated in dollars). Although Depositary Receipts (DRs) can be issued in a number of markets, all of the cross-listed firms from Argentina issued DRs in the United States; consequently, we will refer to Argentine crosslisted shares as ADRs.

${ }^{2}$ Mussa (2002) makes the case that the persistent inability of the Argentine government to run responsible fiscal policy was the primary cause of the economic collapse. Others point to the deleterious effects of an over-valued currency on exports (see, for example, Feldstein (2002)) and the sudden stop in foreign capital inflows (Calvo, Izquierdo, and Talvi (2002)).

${ }^{3}$ A literal translation of "Corralito" is little corral. It is also the word for "playpen."
} 
officially devalued, all bank deposits and debts were "pesofied", and U.S. dollar accounts were no longer permitted.

In contrast to the experiences of other emerging markets, the crisis appears to have been "good news" for the Argentine stock market. ${ }^{4}$ Figure 1 shows the stock market indices (denominated in dollars) in Argentina, Malaysia, Mexico and Thailand during their respective financial crises. ${ }^{5}$ The stock markets in Malaysia, Mexico and Thailand stagnated in the weeks preceding their currency devaluations, and then sharply declined after devaluation. While the market in Argentina was also in a slump two months before the devaluation, the Corralito triggered a 50 percent expansion of the market. One interpretation of the stock market run up in Argentina is that for some reason investors viewed the likely devaluation of the peso as beneficial for firms, whereas in other countries such crises are generally harmful. ${ }^{6}$ The contention of this paper, however, is that the idiosyncratic reaction of the Argentine stock market was largely due to the specific restrictions in the Corralito that allowed investors to use their frozen bank deposits to purchase Argentine stocks, and, in so doing, provided a legal mechanism for transferring funds abroad via ADRs. ${ }^{7}$ Based on data on ADR discounts and trading volume we find that Argentine investors were willing to pay a substantial price to move their deposits out of Argentina through ADR conversions. At their peak, some ADRs were trading at a discount of

\footnotetext{
${ }^{4}$ It is interesting to note that the Argentine stock market began its upturn when the Corralito was first imposed on December $3^{\text {rd }}$, and then rose even higher after President De La Rua and Finance Minister Domingo Cavallo resigned (December 19 and $20^{\text {th }}$ ) when expectations of an impending devaluation intensified. It was not until after the announcement of the devaluation (on January $7^{\text {th }}$ ) that the stock market, measured in US dollars, began its decline.

${ }^{5}$ The vertical line on the figure marks the corresponding devaluation date for each country. The flat intervals in the plot indicate periods when the Argentine market was closed. All returns are measured in U.S. dollars.

${ }_{7}^{6}$ See, for example, Forbes (2002).

${ }^{7}$ It is clear that the Argentine government understood the role ADRs might play in allowing citizens to transfer funds abroad. However, because ADRs were associated with most of the largest publicly traded Argentine companies it would have been difficult for the government to disallow ADR transactions (and risk sending the Argentine stock market into a tail spin). Also, the fact that ADR conversions did not have a direct impact on Central Bank reserves, a topic we will return to, meant that the government was less concerned about this channel of capital outflow.
} 
in excess of 40 cents on the dollar. A rough estimate is that such transactions resulted in a capital outflow of roughly $\$ 835$ million to $\$ 3.4$ billion between December 1, 2001 and May 31, 2002.

[Figure 1 here]

There is an extensive literature on ADRs and their role in the global integration of financial markets (see, for example, the survey by Karolyi (1998)). The holder of an ADR has the right to redeem the receipt for the underlying shares at any point, so that in the absence of capital market restrictions, and adjusting for the exchange rate, the ADR and the underlying share are perfect substitutes. ${ }^{8}$ Cross-listing in the United States allows firms in foreign markets to enjoy the advantages of greater liquidity, transparency and access to the U.S. capital market. ${ }^{9}$ From the perspective of U.S. investors, ADRs are a convenient way of obtaining global diversification. ${ }^{10}$ In general, the literature suggests that ADRs are efficiently priced - after correcting for differences in exchange rates and transactions costs, the law of one price does appear to hold for cross-listed stocks (Kato et al. (1991) and Park and Tavakkol (1994)).

Viewed against this backdrop, Argentina appears to be a unique case in which a country with a significant number of cross-listed stocks and relatively well-integrated financial markets subsequently attempted to close its financial borders. The unusual set of circumstances in Argentina give ADRs a new, and previously unstudied, role as a mechanism for capital flight. ${ }^{11}$ The Argentine case suggests that, once having established ADRs and other kinds of contractual

\footnotetext{
${ }^{8}$ Conversely, the holder of the underlying shares has the option of converting the shares into ADRs. Each ADR denotes a specific number of the underlying shares (which remain on deposit at the depositary's custodian bank in the issuer's home market).

${ }^{9}$ See, for example, Alexander, Eun and Jankiramanan (1987), Foerster and Karolyi (1999), Miller (1999), Ahearne, Griever, and Warnock (2001), and Doidge, Karolyi and Stulz (2002).

${ }^{10}$ See, for example, Officer and Hoffmeister (1987), Whahab and Khanduala (1993) and Jiang (1998). Domovitz, Glen and Madhavan (1997), Errunza, Hogan and Hung (1999), and Karolyi and Stulz (2002) examine the broader influences of ADR programs on the development and integration of markets.

${ }^{11}$ Melvin (2002) also documents the unusual behavior of the Argentine stock market and the role of ADRs during the Corralito period.
} 
arrangements across markets, it may be difficult if not impossible to reverse the process of capital market integration with (even draconian) capital controls.

The paper is organized as follows. Section 2 provides details about the specific restrictions of the Corralito and defines the arbitrage premium/discount between local and U.S. ADR prices. Section 3 examines the behavior of non-ADR and ADR returns pre- and postCorralito and calculates arbitrage bounds for ADRs based on the transactions costs that U.S. and Argentine investors faced during the December 2001 to July 2002 period. We then use the ADR premium to estimate the market's expectation of the devaluation. Section 4 examines the market factors that influenced ADR portfolio returns in New York and Argentina before and after the imposition of the Corralito. Finally, in section 5 we discuss the decline of ADRs as a mechanism for capital outflow in March 2002 and the rise of Argentine certificates of deposit (CEDEARs) as an alternative channel for arbitrage and capital flow.

\section{ADRs, The Corralito and the Argentine Stock Market}

In principle the performance of the Argentine stock market in the pre-devaluation period is puzzling. Just one month before a widely anticipated devaluation of the peso and in the midst of a staggering financial crisis with massive capital outflows and bank runs, the stock market was booming. To place the recent performance of the stock market in some perspective, Figure 2 shows Argentina's stock market index, the Merval, in pesos and U.S. dollars, from January 1990 to April 2002. Argentina's currency board was established in March 1991, triggering a stock market boom that lasted until June 1992. The market was negatively affected by the Mexican crisis in late 1994, and again by the Asian crisis in 1997, but stayed well above its pre-March 1991 level. Beginning in early 2000, however, the market began a steady decline, sliding down to levels not seen in a decade. 
[Figure 2 here]

\subsection{The Corralito}

By mid-2001, years of stagnating economic growth, lagging exports, weak banks and mounting fiscal deficits had taken their toll. In October negotiations over a bailout package with the IMF failed and Argentina was on the brink of financial collapse. To stave off a run on banks and a speculative attack on the peso, on December 1, 2001 Finance Minister Cavallo announced a series of restrictions on bank withdrawals and dollar transfers abroad. Under the Corralito, depositors were limited to withdrawals of 250 pesos per week but could access their accounts to transfer funds within the banking system. ${ }^{12}$ Wire transfers required Central Bank approval, foreign currency futures transactions were prohibited, and in effect, all investors, foreign and domestic, were prohibited from transferring funds abroad. The restrictions were announced as temporary measures that would remain in place until the danger of the speculative attack had passed.

The Corralito, did not, however, restrict investors from trading Argentine securities including those that were cross-listed on another market. Indeed, to do so would have seriously destabilized the local market as it would have prevented investors from trading in some of the largest and most liquid stocks on the market. The ADR "loophole" worked as follows: Argentine residents were allowed to use bank deposits in excess of the $\$ 1,000$ monthly ceiling to purchase Argentine stocks. If a stock happened to be cross-listed in another country those shares could be legally converted from Argentine shares into ADRs. The ADRs could then be sold in the United States and the dollar proceeds deposited in a U.S. account. Under normal circumstances the dollar proceeds would appear in the Argentine Balance of Payments as a 
capital inflow, as U.S. residents have acquired claims on Argentine firms. Under the Corralito, however, the capital inflows did not occur, and the dollars and/or shares remained outside of Argentina. In effect, the ADR "loophole" allowed Argentines to transfer monies abroad, but the transactions did not result directly in a fall in Argentina's international reserves (or a fall in Argentine bank deposits). ADR conversions, however, did reduce the number of (underlying) shares available on La Bolsa.

2.2 Costless and instantaneous arbitrage premia

To help fix ideas, it is useful to define the trade-offs facing U.S. and Argentine investors. We first assume that arbitrage between the two markets is instantaneous and costless. While this is clearly unrealistic, it will establish a useful benchmark for examining transactions costs.

We will use the following definitions:

$P_{t}^{L} \quad=$ price of local shares, in pesos

$P_{t}^{A D R}=$ price of ADR in the United States, in dollars

$S_{t} \quad=$ spot exchange rate, U.S. dollars per peso

$\xi \quad=$ number of underlying shares per unit of depositary receipt

Consider the return to an Argentine investor who purchases local shares and then converts them to an ADR. We take the view that given the extent of dollarization of the Argentine economy, investors were concerned about preserving the dollar value of their assets, and therefore we compute dollar returns. The instantaneous arbitrage premium on holding the ADR is then:

\footnotetext{
${ }^{12}$ Some of the original withdrawal limits were eventually modified, though the main restrictions on capital outflow still remain in place. See Appendix 1 for a detailed timeline of the changes in financial market regulations in Argentina beginning in October 2001.
} 
(1) $\pi_{t}^{1}=\frac{p_{t}^{A D R}-S_{t} \xi p_{t}^{L}}{S_{t} \xi p_{t}^{L}}$

The premium/discount changes with local price, the U.S. price (which is a function of U.S. demand) and the exchange rate.

From the perspective of a U.S. investor, the rate of return would be

(1') $\pi_{t}^{2}=\frac{S_{t} \xi p_{t}^{L}-p_{t}^{A D R}}{p_{t}^{D R}}$

2.3 Arbitrage with transactions costs

Argentine investor

Consider again an Argentine investor in period $t$ who has purchased cross-listed stocks. The investor can sell the stocks in Buenos Aires or transform the stocks into ADRs and sell them in the United States. Transforming the stock into an ADR, setting up a U.S. account and selling the stock takes time, and involves transaction costs and different risks. ${ }^{13}$ Define $\mathrm{n}_{0}$ as the minimum time required to sell the ADR in New York, and consider the following two strategies:

1) Sell the stock in Buenos Aires at $p_{t+n}^{L}$

2) Sell the ADR in New York at $p_{t+n}^{A D R}$

where $n \geq n_{0}$. If the expected return of strategy 2 is larger than the expected return of strategy 1 , then every risk neutral local investor (assuming all the other investing opportunities are arbitraged) would transform their stocks into ADRs and follow strategy 2. On the other hand, under normal conditions risk-neutral local investors would simply hold their local shares when

\footnotetext{
${ }^{13}$ Information from brokers suggests that the time to conversion and the implicit exchange rate used in the conversion process varied considerably across type of investor and across time. For this reason we use contemporaneous prices and exchange rates as a benchmark in computing arbitrage returns.
} 
the expected return of strategy 1 is bigger than expected return of strategy 2 . The expected return (at period t) in U.S. dollars of following strategy 2 is: ${ }^{14}$

$$
\mathrm{E}_{\mathrm{t}} \mathrm{R}_{2}=\frac{E_{t}\left[p_{t+n}^{A D R}\left(1-\tau_{3}\right)\left(1-\tau_{5}\right)\right]-\tau_{4}-\left[\xi p_{t}^{L}\left(1+\tau_{1}+\tau_{2}\right) S_{t}\right]}{\left[\xi p_{t}^{L}\left(1+\tau_{1}+\tau_{2}\right) S_{t}\right]}
$$

where $\xi P_{t}^{L}\left(1+\tau_{1}+\tau_{2}\right)$ is the pesos the investor needs to buy $\xi$ local shares to obtain one ADR, and $E_{t}\left[p_{t+n}^{A D R}\left(1-\tau_{3}\right)\left(1-\tau_{5}\right)\right]$ is the dollar amount that the Argentine investor expects to obtain after selling the ADR in the U.S. at time $\mathrm{t}+\mathrm{n}$ after taxes and expenses. Argentine investors typically face a broker's fee, $\tau_{1}$, and a transactions fee, $\tau_{2}$. A second broker's fee, $\tau_{3}$, is incurred when the asset is sold in the United States. We also include a fixed fee in dollars, $\tau_{4}$, that the investor must pay to transform the regular shares into an ADR. Finally, the cost of opening a bank account in the United States is $\tau_{5}$. Note that the investor does not have to physically obtain dollars to carry out this operation (the return is simply expressed in dollar units) so the investor does not pay a fee for obtaining foreign exchange. Note also that all of the transactions in (2) were permitted under the Corralito.

If the Argentine investor were to instead use the dollar amount $\left[\xi p_{t}^{L}\left(1+\tau_{1}+\tau_{2}\right) S_{t}\right]$ to buy local shares and sell them in Buenos Aires in period $\mathrm{t}+\mathrm{n}$ for the expected (net of taxes) price, her expected return at time $\mathrm{t}$ will be:

$$
\mathrm{E}_{\mathrm{t}} \mathrm{R}_{1}=\frac{E_{t} \xi p_{t+n}^{\mathrm{L}}\left(1-\tau_{1}-\tau_{2}\right) S_{t+n}-\xi p_{t}^{L}\left(1+\tau_{1}+\tau_{2}\right) S_{t}}{\xi p_{t}^{L}\left(1+\tau_{1}+\tau_{2}\right) S_{t}}
$$

Where $\xi p_{t}^{L}\left(1+\tau_{1}+\tau_{2}\right) S_{t}$ is the amount, expressed in dollars, the investor needs in order to buy enough shares of the local stock to reach the equivalent of one ADR, and $E_{t} \xi p_{t+n}^{\mathrm{L}}\left(1-\tau_{1}-\tau_{2}\right) S_{t+n}$

\footnotetext{
${ }^{14}$ Here we are assuming the conversion fee is paid in dollars in the U.S. once the operation is complete, and the amount is withdrawn from the investor's banking account.
} 
is the amount of money she receives for selling the shares after $\mathrm{n}$ periods. The returns are calculated net of the broker's fee and the local transactions fee.

For the investor to be willing to convert shares to ADRs, it must be the case that $\mathrm{E}_{t} \mathrm{R}_{1} \leq$ $\mathrm{E}_{\mathrm{t}} \mathrm{R}_{2}$ or

$$
E_{t}\left[p_{t+n}^{A D R}\left(1-\tau_{3}\right)\left(1-\tau_{5}\right)\right]-\tau_{4}-E_{t}\left[\xi p_{t+n}^{\mathrm{L}}\left(1-\tau_{1}-\tau_{2}\right) S_{t+n}\right] \geq 0
$$

\section{U.S. investor}

We next derive the trade-off facing a U.S. investor. The trade-off is different for the two investors because of the asymmetries in fees, taxes and institutional regulations in the two markets. The U.S. investor purchases the ADR in the U.S. and can either

I) Sell the ADR in New York at $p_{t+n}^{A D R}$ or

II) Sell the stock in Buenos Aires at $p_{t+n}^{L}$.

The first strategy gives the expected return to holding the ADR for $\mathrm{n}$ periods:

$$
\mathrm{E}_{\mathrm{t}} \mathrm{R}_{\mathrm{I}}=\frac{E_{t} p_{t+n}^{A D R}-p_{t}^{A D R}}{p_{t}^{A D R}}
$$

U.S. investors do not face a broker's fee or a stock market transactions fee. ${ }^{15}$ The return to converting the ADR to local shares, and repatriating the earnings is given by:

$$
\mathrm{E}_{\mathrm{t}} \mathrm{R}_{\mathrm{II}}=\frac{E_{t} \xi p_{t+n}^{\mathrm{L}}\left(1-\tau_{1}-\tau_{2}\right)\left(1-\tau_{6}\right) S_{t+n}-p_{t}^{A D R}}{p_{t}^{A D R}} .
$$

When selling the shares in Argentina, we assume that the U.S. investor incurs charges in using a local broker and must pay the stock market transactions fee. Since we assume that he would like to return the profits from the sale back to the U.S., he incurs an additional tax $\left(\tau_{6}\right)$ for

\footnotetext{
${ }^{15}$ It is not strictly true that U.S. investors face zero transactions costs. However, our empirical analysis focuses on the arbitrage conducted by Argentine investors during the Corralito, so we abstract from the relatively small U.S. transaction costs for simplicity.
} 
transferring the funds. Note that under the Corralito repatriating the dollars directly is illegal. Presumably there are other means of circumventing the controls, but by ignoring these restrictions we are in effect understating the transactions costs faced by U.S. investors.

A risk-neutral investor will cancel an $\mathrm{ADR}$ when $E_{t} R_{I} \geq E_{t} R_{I I}$ or:

$$
E_{t} \xi p_{t+n}^{\mathrm{L}}\left(1-\tau_{1}-\tau_{2}\right)\left(1-\tau_{7}\right) S_{t+n}-p_{t}^{A D R} \geq 0
$$

This suggests that if local prices (expressed in dollars) exceed the ADR price investors should buy ADRs, convert them back to local shares and sell them in Argentina.

\section{Arbitrage bounds}

The trade-offs faced by Argentine and U.S. investors yield arbitrage bounds for capital inflow into and outflow from the Argentine market. Equation (4) can be rewritten to show the bound facing an Argentine investor who is contemplating converting his local stocks into an ADR:

$$
\frac{\left(1-\tau_{1}-\tau_{2}\right)}{\left(1-\tau_{3}\right)\left(1-\tau_{5}\right)}+\frac{\tau_{4}}{\left(1-\tau_{3}\right)\left(1-\tau_{5}\right) E_{t} \xi p_{t+n}^{L} S_{t+n}}-1 \geq \frac{E_{t} p_{t+n}^{A D R}-E_{t} \xi p_{t+n}^{L} S_{t+n}}{E_{t} \xi p_{t+n}^{L} S_{t+n}}
$$

Capital outflows to the U.S. will not occur if the transaction costs on the left-hand-side of (8) (which are a function of the local price and the exchange rate) exceed the returns to the conversion.

Equation (9) shows the corresponding arbitrage bound for capital inflows into Argentina. If the transactions costs faced by a U.S. investor are less than the returns of selling ADRs for local shares then we should observe capital inflows into Argentina.

$$
\left(1-\tau_{1}-\tau_{2}\right)\left(1-\tau_{6}\right)-1 \geq \frac{E_{t} \xi p_{t+n}^{L} S_{t+n}-E_{t} p_{t+n}^{A D R}}{E_{t} \xi p_{t+n}^{L} S_{t+n}}
$$


If the ADR premia/discount lies between the bounds in (8) and (9) neither investor would engage in arbitrage between the markets. Premia outside of the bounds should, in principle, be arbitraged away. In the section below we use estimated transactions costs during the Corralito to calculate the arbitrage bounds.

\section{ADR premia during the Corralito}

Table 1 provides a list of ADRs listed in Argentina as of December 1, 2001. The top part of the table lists the shares that are publicly traded in the United States and Argentina. These 12 companies will be the sample for most of our analysis. The remaining 11 shares are traded over the counter (Rule 144a and OTC stocks) and as such are not required to meet U.S. accounting standards. ${ }^{16}$ In December 2001, the 12 ADRs in Table 1 accounted for $85 \%$ percent of the Merval.

\section{[Table 1 here]}

During the Corralito, ADRs played three roles for Argentine investors. ADRs provided (1) liquidity value (they allowed asset transformation of bank deposits - which could potentially be expropriated by the government or lost in a full-scale bank run -- into stocks); (2) capital control circumvention value (they allowed investors to legally deposit dollars abroad); and (3) hedge value (against the likely devaluation of the dollar value of the peso). The first effect, asset transformation, should increase the value of all Argentine stocks during the Corralito, and the premium associated with asset transformation should remain until all depositors in Argentina have re-optimized their savings portfolios or the deposit restrictions are removed. The second effect, capital outflow, should appear as an additional premium in ADR prices over non-ADR prices in Argentina, and again should last until all Argentine investors are indifferent between 
holding their assets at home or abroad. This could be achieved either when all of the available funds have left the country, or the cost of moving funds becomes prohibitively high. The third effect, the exchange rate hedge, will be an additional premium associated with ADRs until the devaluation takes place.

The difference in the ADR premium post- and pre-devaluation yields the market forecast of the magnitude of the devaluation. In effect, prior to the devaluation the stock market served as a shadow exchange market and we exploit this to back out expectations of the devaluation. After the devaluation there still exists exchange rate risk, but it is now priced in the foreign exchange market rather than in the stock market.

Figure 3 shows price indices for equal-weighted portfolios of $\mathrm{ADRs}^{17}$ and all other Argentine stocks over the July 1, 2001 to May 31, 2002 period. As predicted, both portfolios reverse their downward trend in the pre-Corralito period, increasing immediately following the imposition of capital controls. The ADR portfolio experiences a bigger increase than the nonADR portfolio, reflecting the second two effects discussed above. The additional premium on ADR stocks over non-ADR stocks remains until May 2002. We also observe a dramatic change in the trading volume in ADRs in Argentina. Figure 4 shows the steady decline in the aggregate trading volume on La Bolsa over the last two and a half years. However, as shown in Figure 5, the fraction of ADRs in the total volume traded jumps dramatically at the time of the Corralito from roughly 40 percent of the total volume to over 80 percent. Perez Companc alone accounted for nearly 50 percent of the total volume of trading in the month of December 2001.

\footnotetext{
${ }^{16}$ We dropped Nortel from our ADR portfolio even though it is not an OTC stock because it is a preferred stock with very few transactions over this period.

${ }^{17}$ We use the equal-weighted portfolio to get a better sense of the movement in all share prices and to reduce idiosyncratic noise. Using the value-weighted portfolio reflects mainly movements in YPF, with a market capitalization that represents $44 \%$ of the ADR portfolio, and Perez Companc, with a market capitalization that represents another $16 \%$ of the ADR portfolio.
} 
[Figures 3, 4 and 5 here]

Table 2 examines the changes in prices of the ADR portfolio and individual ADRs following the imposition of the Corralito, Cavallo's resignation on December 19, 2001 and the announcement of the discontinuation of the currency board on January 4, 2002. ${ }^{18}$ (All prices are measured in U.S. dollars). In the week following the imposition of the Corralito, the ADR portfolio jumped 7.6 percent. There is considerable heterogeneity in the price responses of different ADRs ranging from increases of 23 percent for Siderca and 15.6 percent for Perez Companc to a decline of 1.6 percent for IRSA. Cavallo's resignation, which increased the likelihood of a devaluation, increased the value of ADRs even further. The ADR portfolio increased an additional 7.5 percent and Metrogas, TECO and Perez Companc increased over 30 percent in value. All dollar share prices fell after the devaluation, reflecting the change in the exchange rate.

[Table 2 here]

\section{Changes in ADR premia}

Changes in Argentine prices during the Corralito tell only part of the story. We now turn to the arbitrage premia/discount on Argentine shares relative to the price of ADRs in the U.S. Figures 6 and 7 show local and U.S. prices in dollars and the ADR discounts for two (Perez Companc and Siderca) of the 12 companies in our sample of ADRs over the July 1, 2001 to May 31, 2002 period. ${ }^{19}$ The figures also show the arbitrage bounds based on our estimates of

\footnotetext{
${ }^{18}$ The devaluation was announced on January $7^{\text {th }}$ and took place on January $11^{\text {th }}$ (to a new exchange rate of 1.4). The free float started on February 11th. See appendix 2 for more information regarding exchange rate developments over this period. Note also that the stock market was closed on several days over this period which may have impacted the behavior of returns. We simply use observable prices on day when the market was open in our calculations.

19 Similar figures for the rest of the ADRs are available upon request.
} 
transactions costs (see Table 3 ). ${ }^{20}$ The bottom half of Table 2 summarizes the average discounts during pre-Corralito, Corralito pre-devaluation and post-devaluation periods for each company and the averages across the twelve companies. ${ }^{21}$

[Figures 6 and 7 here]

[Table 3 here]

The information in Table 2 and the plots indicate that the average pre-Corralito

premium for all companies except Metrogas was close to zero, suggesting that arbitrage between Argentina and the U.S. kept prices in close alignment. During the Corralito, the average ADR discount (the local price less the ADR price) jumped to 20 percent. The plots suggest that the ADR discounts were relatively small at the beginning of the Corralito and peaked just prior to the devaluation. One interpretation of this evidence is that the shadow value of the exchange rate hedge via ADRs increased as the devaluation became more likely in early January 2002. At their peak, the discount reached close to 40 cents on the dollar for Banco Frances, Banco Galicia, Perez Companc and Siderca. ${ }^{22}$

\footnotetext{
${ }^{20}$ The transactions costs we use in the calculations (based on conversations with brokers and investment bankers in Argentina) are: $\tau_{1}=.3025 \tau_{2}=.1025 \tau_{3}=.3025 \tau_{4}=.2 \tau_{5}=1.0$. In table 3 we provide transaction cost ranges that reflect amounts that were charged to both small and large Argentine investors. Our sources indicate that the standard length of time required for an ADR conversion was nine days. Large investors, such as institutional investors and bankers faced substantially lower costs than smaller investors, and could also complete the ADR conversion in a shorter period of time. We ignore the time delay in our calculations of premia/discounts. The difference between the lower bound and upper bound in our estimations is around 500 basis points. Rabinovitch, Silva and Susmel (2000), using data for 6 Argentinean stocks with ADRs for the period 1993-2000 estimate arbitrage bands of around 270 basis points, suggesting both that transactions costs increased during the Corralito and that the transactions fees we use in our calculations provide maximum arbitrage bands.

${ }^{21}$ Here the adjustment to the law of one price is apparently accomplished in the Argentinean price rather than the U.S. ADR price. Huang and Stoll (2001), find a similar adjustment in the 1992 UK crisis (where the local price jumped to adjust to the expected devaluation), but for 1994 Mexico, they find that the adjustment was in the Mexican ADR price, rather than in the local price.

${ }^{22}$ According to brokers and the financial press, the most demanded ADRs have been (in order of importance): Perez Companc (PC), Grupo Financiero Galicia, Siderca and Telecom. In December 2001, the number of shares of PC traded in NYSE increased $170 \%$. The likely reason investors preferred these specific stocks is that they were the ones with the highest liquidity in the U.S. market. Our preliminary research on the cross sectional differences in the stocks' premia (based on panel data) confirm that liquidity seems to be the most important factor in explaining the differences in premia across firms.
} 


\section{Expected Devaluation}

We use three methods to estimate the market's expectation of the magnitude of the devaluation on January $11,2002 .{ }^{23}$ The first measure is to look at the price impact of Cavallo's resignation on December 19, 2001. It could be argued that up to that point the Corralito was still viewed as a temporary measure to bolster the peg. The news of the resignation was clearly a signal that the peg would be abandoned. Column B in Table 2 shows the weekly change in the local price of ADRs before and after the resignation. On average, prices jumped 16.7 percent, suggesting a roughly 17 percent increase in the value of the exchange rate hedge. ${ }^{24}$

The second measure of the anticipated devaluation is to examine the difference between the ADR discount in the pre- and post-devaluation periods. Under the assumption that the shadow value of ADRs as a means of converting bank deposits and for capital outflow over the period remained constant, the difference between the pre- and post-devaluation periods isolates the value of the exchange rate hedge. The difference between the average discount in the two periods is shown in Table 2 column G. The difference ranges considerably across ADRs, averaging out to roughly $8 \%$. This is likely to be an understatement of the hedge term, however, because the ADR discount started small and increased dramatically in the pre-devaluation sample. It is more likely that prices on the eve of the devaluation came closest to reflecting the market's expectation of the change in the exchange rate. Using the discounts just before and just after the devaluation as our measure, column $\mathrm{H}$ shows an average devaluation of 40.4 percent (with a range of between 19 and 76 percent). This is larger than the other two estimates and it is

\footnotetext{
${ }^{23}$ Becjker, Gelos and Richards (2002) estimate devaluation expectations from the relative performance of a cross section of Mexican publicly traded firms around the 1994 peso crash. Using an estimate of the exchange rate exposure of the different firms, they construct a measure of the shadow exchange rate prior to devaluation. In future research we will further explore the information from our cross-section of ADRs for alternative measures of expected devaluation.

${ }^{24}$ One could also argue that the resignation was a further sign of political instability, which would also increase the demand for ADRs as vehicles for capital outflow.
} 
exactly the magnitude of the official devaluation for foreign trade operations, although it is less than the free market rate devaluation of 70 percent that applied to all other transactions.

In addition to calculating the expected magnitude of the devaluation, we can use ADR transactions data to estimate the magnitude of capital outflow. The most accurate measure of the volume of outflow would be to use the number of ADR conversions that occurred after the imposition of the Corralito. Unfortunately, these figures are not publicly available. An alternative measure is to take the post-Corralito cumulated volume of sales of Argentine ADRs in New York, under the assumption that all ADR sales reflect cashing out by Argentine investors. This figure comes to $\$ 835$ million. ${ }^{25}$ This is likely to be an underestimate of the volume of outflow, since many investors may simply hold the stock rather than sell at depressed prices. Another measure is the cumulated volume of purchases of local stocks with associated ADRs in Buenos Aires over this period. Under the assumption that all these purchases are intended for ADR conversion, the value of capital outflow comes to $\$ 3.4$ billion dollars. This is likely an overestimate, since Argentines may have had other reasons for purchasing these stocks besides ADR convertibility.

\section{Market Factors and the Pricing of ADRs}

Until this point, we have analyzed the time series of ADR and local prices in isolation. We now turn to the pricing of ADR stocks in the context of overall market movements in Argentina and New York.

In theory, in a fully liberalized and integrated financial environment, we would expect ADRs to be priced based on global market factors. Investors with access to global assets should expect returns to be based on covariances of individual stocks and the global market portfolio.

\footnotetext{
${ }^{25}$ This is the cumulated sum between December 1, 2001 and May 31, 2002.
} 
That said, in practice, Karolyi and Stulz (2002) find that home bias tends to increase local influences on asset prices. They find that local market portfolios often better explain the crosssectional variation in expected returns for local stocks, though they also find that equity flows and cross-country correlations increase global influences on asset prices. ${ }^{26}$ The pricing of Argentine ADRs provides an interesting natural experiment in the context of this literature. Prior to the imposition of the Corralito, Argentina's financial markets were considered fully liberalized. The Corralito, although allowing ADR transactions to continue, was intended to control capital outflows and therefore presumably led to a less globally integrated Argentine capital market. In terms of the market model, we should therefore expect that local market factors in Argentina became more important in pricing stocks with associated ADRs during the period in which capital controls were in force.

We test whether the imposition of the Corralito led to changes in the pricing of Argentine stocks with associated ADRs using a standard market model; where $R_{i t}$ is the return on asset $\mathrm{i}$ at time $\mathrm{t}, R_{f t}$ is the return on the risk-free rate at time $\mathrm{t}, R_{m t}^{G}$ is the return on the global market portfolio at time t, and $R_{m t}^{L}$ is the return on the local market portfolio at time t:

$$
R_{i t}-R_{f t}=\beta_{1}\left(R_{m t}^{G}-R_{f t}\right)+\beta_{2}\left(R_{m t}^{L}-R_{f t}\right)+\varepsilon_{i t} .
$$

Evidence of market segmentation would be indicated by a significant coefficient on the local market index, $\beta_{2}$. Table 4 presents daily time series results ${ }^{27}$ from regressions of returns from the

\footnotetext{
${ }^{26}$ Also see Errunza and Losq (1985), Eun and Janakiramanan (1986) and Alexander et al (1987) who examine the pricing of ADR portfolios in the context of the market model and generally find evidence that global market factors dominate local factors in explaining ADR returns.

${ }^{27}$ Daily returns correspond to close-to-close prices including dividends and excluding weekends and holidays. A potential problem with daily market model regressions is the occurrence of non-overlapping trading hours across markets due to different time zones, trading schedules and country-specific holidays. In our study, the extent of nonsynchronous trading across national stock markets is compounded by the fact that the Argentine stock market was closed for several days during the height of the crisis. We include dummy variables in the regressions to control for the possibility of abnormal returns after these market closures and in future drafts of the paper we will include the Scholes and Williams (1977) non-synchronous trading correction.
} 
portfolio of Argentine stocks that have associated ADRs on the Morgan Stanley Capital International (MSCI) world index and an orthogonalized local Argentine equal-weighted portfolio index (excluding the stocks with associated ADRs). ${ }^{28}$ Regression results are presented both for the period prior to the imposition of the Corralito (specifically October 1997 through November 2001) ${ }^{29}$ and for the post-Corralito period (over rolling subperiods to take into account potential parameter instability). ${ }^{30}$

[Table 4 here]

The results in table 4 suggest that both Argentine market factors and global market factors were important in pricing Argentine stocks with associated ADRs even before the imposition of the Corralito. In the period when the Corralito was in place, both indices continue to be statistically significant, though the beta on the Argentine market index is typically larger in magnitude. The beta on the Argentine market index rises almost twofold (to 1.5) in the two months immediately following the imposition of the Corralito, indicating that stocks with associated ADRs magnified Argentine market movements in this period. These results confirm our initial hypothesis that local market factors in Argentina became more important in pricing

\footnotetext{
${ }^{28}$ The correlation between the MSCI and the non-ADR Argentine portfolio is quite high (.53 for the period October 1997 - July 2002). We therefore orthogonalize the non-ADR Argentine portfolio by regressing it on the MSCI and use the residuals from this first stage regression for $R_{m t}^{L}$ in the estimation of equation 10 .

${ }^{29}$ In the pre-Corralito subperiod regressions seven dummy variables are also included as independent variables in the market model as controls for days on which we might expect abnormal returns due to non-market factors. The first dummy variable indicates dates when the Argentine market was closed due to holidays, the second indicates days when the Argentine market was closed for other reasons (days on which the New York market was closed are omitted). And, the other five dummy variables were included to indicate the day on which a new ADR was included in the ADR portfolio (Banco Galicia entered on 7/4/2000, APSA on 11/15/2000, PC on $1 / 26 / 2000$, Nortel on 6/19/1997 and Siderca on 5/21/2001) as we might expect the return on the overall ADR portfolio to rise on these days in reaction to its new composition. These estimates are not reported in the tables but are available upon request. ${ }^{30}$ In the post-Corralito subperiods we also include the change in the peso/dollar exchange rate as a third factor in the market model to control for the large devaluation that took place on January 11, 2002. The coefficient on the exchange rate term is generally statistically significant and ranges in magnitude from .1 to .5 depending on the subperiod. This coefficient can also be interpreted as an estimate of the peso exposure of the ADR portfolio.
} 
stocks with associated ADRs (and presumably all Argentine stocks) during the period in which capital controls were in force.

The model in section 2 and the data description in section 3 of this paper suggest that the pricing of ADR stocks in Argentina and New York may have diverged during the Corralito period. And, in particular, we might expect that while local factors influenced prices in Argentina (as reported in table 4), they may not have been as important for prices of the same stocks sold in New York (given that investors in New York were not subject to the restrictions of the Corralito). Table 5 presents time series results from regressions of Argentine ADR portfolio returns in New York (NYSE and Nasdaq) on the MSCI world index and an orthogonalized local Argentine equal-weighted portfolio (excluding the ADRs).

\section{[Table 5 here]}

The results for the pricing of ADR stocks in the post-Corralito subperiod reported in table 5 differ markedly from those in table 4 . Recall that the dependent variable for the regressions reported in table 4 is the return in Argentina of a portfolio of stocks with associated ADRs, while in table 5 we examine the pricing of these same stocks after they are converted to ADRs and traded in New York. In both sets of tests the results in the pre-Corralito period are similar. The results suggest that although the Argentine market was relatively more integrated before the imposition of the Corralito - it is still the case that local (Argentine) market factors as well as global factors were important in explaining ADR portfolio returns in both Argentina and New York. In the period immediately following the imposition of the Corralito (and when volume in the ADR market was at its peak) neither the global market index nor the Argentine market index explain ADR portfolio returns in New York (whereas in Argentina local market factors become more important in explaining the pricing of stocks with associated ADRs over 
this period). In the subsequent two-month rolling subsamples the global market index beta regains statistical significance and rises in magnitude for the ADR portfolio returns in New York. The coefficient on the local market index also regains statistical significance, though the size of the local market beta falls dramatically from .88 in the pre-Corralito subperiod to .08 in the subperiod including January through March 2002. ${ }^{31}$ These results suggest that after the imposition of the Corralito Argentine market factors no longer had as much influence on the pricing of Argentine ADRs in New York. Or, put another way, ADRs in New York became less like other Argentine stocks (including those with associated ADRs) with the advent of capital controls.

\section{The Emergence of the CEDEAR market}

In late February 2002 volume in the ADR market, which had reached its peak in December 2001 just after the imposition of the Corralito, leveled off. ${ }^{32}$ Although the Corralito continued to be in effect, several regulatory changes, starting in February 2002, may have diminished investor's incentives to use the stock market as a means to gain access to frozen assets. $^{33}$ At the same time as interest in ADRs was stalling, volume in the CEDEAR (certificados de depositos Argentinos) market began to rise dramatically, so much so that by May 2002 volume in CEDEARs exceeded volume in all other listed stocks on La Bolsa.

\footnotetext{
31 The regression goodness of fit also falls dramatically from .55 in the pre-Corralito period to .17 for the period January through March 2002.

${ }^{32}$ This is particularly true in New York where ADR volume declines steadily from its peak in December 2001. Volume in February 2002 was 18 percent lower than the previous December, and by May 2002, volume was a mere $23 \%$ of what it had been in December 2001.

${ }^{33}$ In February investors were allowed to withdraw (once and for all) 7,000 U.S. dollars from any of their bank accounts. In March investors were given the option to convert deposits into bonds (in pesos or dollars) and they were allowed to use their deposits to purchase properties, and more recently, cars.
} 
CEDEARs are shares of non-Argentine firms (mostly U.S. firms) that are crosslisted on the Argentine exchange and sold for pesos. ${ }^{34}$ They were first introduced on the Argentine stock exchange in 1997, though volume in the market was negligible until late February 2002. ${ }^{35}$ Before the imposition of the Corralito it is not clear why an investor would have preferred holding a CEDEAR (in pesos) to holding the foreign stocks directly (and in dollars), especially given that they had to pay high conversion fees for the CEDEARs. However, after the imposition of the Corralito investors were no longer able to use dollars to purchase nonArgentine stocks. Indeed, one of the few ways investors were able to gain access to their frozen bank deposits was to purchase shares on La Bolsa. For this reason we might have expected Argentine demand for CEDEARs to have increased during the Corralito and especially after the devaluation, both because underlying CEDEAR assets are denominated in dollars (although CEDEARs are priced in pesos), and because holding shares of non-Argentine firms would serve as a better means of hedging against the looming economic crisis. Volume in the CEDEAR market, however, did not immediately pick up in large part because there was little incentive for anyone to convert U.S. stocks into peso denominated CEDEARs before the devaluation. ${ }^{36}$

Starting in late February 2002, however, liquidity in CEDEAR stocks gradually increased. Discussions with brokers in Argentina suggest that the increase in CEDEAR liquidity came from three sources. First, mutual funds, pension funds and other institutional investors are required to hold assets rated above BBB, and at this time all Argentine stocks and bonds were below the minimum ranking, forcing these funds to purchase non-Argentine

\footnotetext{
${ }^{34}$ Most CEDEARs are issued by Deustche Bank, which acts as the depositary bank, and is the only authorized institution that can transform CEDEARs back into shares sold on U.S. exchanges. The most traded CEDEARs in this period included Cisco Systems, Honeywell, International Paper, JP Morgan Chase and Wal-Mart stores.

${ }^{35}$ In December 2001 the volume of CEDEARs was approximately $0.2 \%$ of the total volume traded (stocks plus CEDEARs) on La Bolsa, whereas in June 2002 CEDEARs made up $70 \%$ of total volume traded.

${ }^{36}$ Traders had little incentive to convert U.S. stocks into CEDEARs prior to the devaluation both because of peso value uncertainty and because the Corralito restricted repatriation of any peso returns.
} 
securities. Since the Corralito disallowed direct purchases of foreign assets CEDEARs were among the few assets that they could acquire. Second, Argentines who held dollars abroad (possibly as a result of an earlier sale of ADRs) started to purchase U.S. stocks with CEDEAR conversions, and re-sell the CEDEARs in Argentina for pesos, as a means to bring monies back into Argentina (and at the same time gaining the CEDEAR premium). ${ }^{37}$ Third, using operations called "via cable" investors were able to buy foreign bank checks that allowed them to purchase the underlying U.S. shares, convert these into CEDEARs, and then sell the CEDEARs (at a premium) in Argentina for pesos. ${ }^{38}$

Once liquidity in the CEDEAR market was established, investors had an alternative means of escaping the Corralito, by purchasing CEDEARs in Argentina for pesos, converting them back to the underlying dollar denominated stocks, and selling them in New York for dollars (that then are deposited in dollar accounts). ${ }^{39}$ The transaction costs of CEDEAR conversion are similar to those in the ADR market, and the increased demand for CEDEARs in Argentina led to similar price spreads on CEDEARs in Argentina relative to the underlying prices of the stocks in New York. Before the Corralito, the mean CEDEAR premium was approximately zero, but in March 2002 the premium increased to 5 percent. $^{40}$

There is clear indication that the Argentine government understood that CEDEARs were serving a similar purpose as ADRs in allowing investors to transfer funds (legally) outside

\footnotetext{
${ }^{37}$ One reason to do this was that after "the pesofication" investors could repay dollar debts with pesos.

${ }^{38}$ Another way that CEDEARs may have been created is through a practice termed "pre-releasing" where the Depositary Bank lends out the underlying securities that make up the CEDEAR to brokers in the market. The brokers then sell the CEDEARs to investors who pay in pesos and then request that the broker convert the CEDEARs back into the underlying U.S. shares (and sell them in New York for dollars).

${ }^{39}$ Investors also purchased (in pesos) dollar denominated Argentine government bonds (specifically Global 2008s) and re-sold them in New York (for dollars) for similar reasons.

${ }^{40}$ Since liquidity for most of the CEDEARs in Buenos Aires is low and the transactions occur at irregular and infrequent intervals, we calculate the premium for each of the CEDEARs on the days when there is a closing price in both markets. The index is then the average of the daily premia. This is obviously a rough measure of the CEDEAR premia, and we leave a complete analysis of this market to future analysis.
} 
of Argentina. On March 25, 2002 a report in the official BCRA press communication suggests

that the government considered adopting new measures to avoid capital outflows using ADR and

CEDEAR transactions. However, no restrictions were imposed at that time. In September 2002, regulations were changed that increased the cost of conversions. ${ }^{41}$ Despite the increased costs, ADR and CEDEAR market conversions continue to take place.

\section{Conclusions}

Argentina in late 2001 and early 2002 provides an unusual opportunity to analyze the reactions of investors to capital controls. The Corralito, originally put in place to stave off a devaluation of the peso, effectively served to provide incentives for Argentines to invest in the Argentine stock market, helping to fuel a boom in La Bolsa even as the Argentine economy was headed toward collapse. The Corralito also provided a new role for ADRs as a (legal) mechanism for capital flight. Investors were able to purchase Argentine stocks with associated ADRs for pesos in Argentina, convert them into ADRs, re-sell them in New York for dollars and deposit the dollar proceeds in U.S. bank accounts.

In the paper we show that ADR discounts went as high as $60 \%$ in the pre-devaluation period, indicating that Argentine investors were willing to pay significant amounts in order to move their funds abroad and to hedge the dollar value of their assets. In effect, the stock market served as a shadow exchange market, which allows us to back out the market's implicit forecast

\footnotetext{
${ }^{41}$ The central bank passed a very restrictive regulation (circular \#3723) that mandated that every stock be traded in its original currency. Since access to dollars and the use of dollars was greatly restricted already, this effectively killed the CEDEAR market. After intense opposition from the financial community, the central bank rescinded \#3723 and instead passed a resolution (circular \#3727) that forbids "contra cable" operations. These operations allowed brokers to sell stocks purchased in Buenos Aires instantaneously in New York (or any foreign market) using the Mercado de Valores as a clearinghouse. Under \#3727 it is still possible for investors in Argentina to convert CEDEARs and sell them in New York, but this new restriction significantly increases the transactions costs to do so. CEDEAR trading volume has fallen more than $35 \%$ since "contra cable" operations were disallowed.
} 
of the size of the devaluation. On the eve of the devaluation, we estimate that the market (correctly) anticipated a 40\% devaluation.

We also test whether the imposition of the Corralito led to changes in the underlying pricing structure of ADR stocks in Argentina and New York. The Corralito, although allowing ADR transactions to continue, was intended to control capital outflows and therefore should have led to a less globally integrated Argentine capital market. We find strong evidence of an increase in Argentine market segmentation after the imposition of the Corralito. We find that local market factors in Argentina became more important in pricing peso denominated stocks with associated ADRs, though we find that the same ADRs in New York are mainly priced based on global factors.

Argentine investors continue to use financial markets, and increasingly the CEDEAR market, to gain access to their frozen bank deposits and to place their assets abroad in dollar accounts. We estimate that capital outflow using the ADR market over the December 2001 to May 2002 amounted to $\$ 835$ million to $\$ 3.4$ billion. If we include capital outflows via CEDEARs and other cross-listed securities, it is likely that the amount of capital that has (legally) left Argentina since the imposition of the Corralito is many times higher. 


\section{References}

Ahearne, A., Griever, W., Warnock,F., 2001. Information costs and home bias: an analysis of U.S. holdings of foreign equities. Working Paper, FRB Board of Governors.

Alexander, G., Eun, C., Janakiramanan, S., 1987. Asset Pricing and Dual Listing on Foreign Capital Markets: A Note. Journal of Finance 42, 151-158.

Bailey, W., Chan, K., Chung, P., (2000). Depositary Receipts, Country Funds, and the Peso Crash: The Intraday Evidence. Journal of Finance 55, 2693-2717.

Becjker, T., Gelos, G.,Richards,A., 2002. Devaluation Expectations and the Stock Market: A New Measure and an Application to Mexico 1994/1995. International Journal of Finance and Economics 7, 195-214.

Calvo, G., Izquierdo, A., Talvi,E., 2002. Sudden Stops, the Real Exchange Rate and Fiscal Sustainability: Argentine Lessons. Paper Presented at the Annual Meetings of the Board of Governors, Inter-American Development Bank.

Doidge, C., Karolyi, G.A., Stulz,R., (2002). Why Are Firms that List in the U.S. Worth More? Ohio State University working paper.

Domowitz, I., J. Glen, and A. Madhavan., 1997. Market Segmentation

and Stock Prices: Evidence from an Emerging Market. Journal of Finance 52 (3), 1059-1085, 1997.

Errunza, V., Hogan K, Hung, M., 1999. Can The Gains From International

Diversification Be Achieved Without Trading Abroad?, Journal of Finance, 54, 2075-2107.

Errunza, V., Losq, E., 1985. International asset pricing under mild segmentation: theory and test. Journal of Finance 40, 105-124.

Eun, C., Janakiramanan, S., 1986. A model of international asset pricing with a constraint on the foreign equity ownership. Journal of Finance 41, 897-913.

Feldstein, M., 2002. Argentina's Fall: Lessons from the latest financial crisis. Foreign Affairs, March/April issue.

Foerster, S., Karolyi, G.A., 1999. The effects of market segmentation and investor recognition on asset prices: evidence from foreign stocks listing in the US, Journal of Finance 54, 981-1013.

Forbes, K. 2002, How do large depreciations affect firm performance? NBER Working Papre \# 9095.

Huang and Stoll, 2001. Exchange rates and firms' liquidity: evidence from ADRs. Journal of International Money and Finance 20,297-325. 
Jiang, C. X., 1998. Diversification with American Depositary Receipts: The Dynamics and the Pricing Factors. Journal of Business Finance and Accounting 25, 683-699.

Karolyi, G.A., 1998. Why do companies list shares abroad? A survey of the evidence and its managerial implications, financial markets. Financial Markets, Institutions and Instruments 7, 160 .

Karolyi, G.A., Stulz, R.M., 2002. Are Financial Asset Priced Locally or Globally? forthcoming in The Handbook of the Economics of Finance, George Constantinides, Milton Harris and René Stulz, editors, North-Holland, Amsterdam, The Netherlands.

Kato, K., Linn, S., Schallheim, J., 1991. Are there arbitrage opportunities in the markets for American depositary receipts? Journal of International Financial Markets Institutions and Money $1,73-89$.

Kim, M., Szakmary, Andrew, C. and Mathur, I., 2000. Price Transmission Dynamics Between ADRs and their Underlying Foreign Securities. Journal of Banking \& Finance, 24, 1359 - 1382.

Melvin, M., 2002. A Stock Market Boom during a Financial Crisis? ADRs and Capital Outflows in Argentina, mimeo, June.

Miller, D.P., 1999. The market reaction to international cross-listings: evidence from depositary receipts. Journal of Financial Economics 51 (1), 103-123.

Mussa, M. 2002. Argentina and the Fund: From Triumph to Tragedy. Institute for International Economics, Washington D.C.

Officer, D., Hoffmeister, R., 1987. ADRs: A substitute for the real thing? Journal of Portfolio Management 13, 61-65.

Park, J., Tavakkol, A., 1994. Are ADRs a dollar translation of their underlying securities? Journal of International Financial Markets, Institutions and Money 4, 77-87.

Rabinovitch, R., Silva, A.C., Susmel, R., 2000. The Impact of Capital Controls and Transaction Costs on the Return Distribution of Dually Traded Securities: Evidence from Chile and Argentina. Department of Finance, CBA, The University of Houston, Houston.

Scholes, M and J. Williams., 1977. Estimating Beta from Nonsynchronous Data. Journal of Financial Economics 5, 309-32.

Wahab, M., Khanduala, A., 1993. Why not diversify internationally with ADRs? Journal of Portfolio Management 20, 75-82. 
Table 1 Argentine Stocks Cross-Listed in the United States

$\begin{array}{cccc} & \text { RATIO } & & \\ \text { SYMBOL EXCH } & \text { ADR:ORD } & \text { INDUSTRY } & \text { EFF. DATE }\end{array}$

ADRs

\begin{tabular}{|c|c|c|c|c|c|}
\hline ALTO PALERMO S.A. & APSA & NASDAQ & $1: 40$ & Real Estate & 10-Nov-00 \\
\hline BBVA BANCO FRANCES S.A. & BFR & NYSE & 1:03 & Banking & 1-Nov-93 \\
\hline CRESUD S.A.C.I.F. Y A. & CRESY & NASDAQ & $1: 10$ & Food-Agribus-Tobacco & 18-Mar-97 \\
\hline GRUPO FINANCIERO GALICIA & GGAL & NASDAQ & $1: 10$ & Fin Serv-Investment & 22-Jun-00 \\
\hline IRSA INVERSIONES Y REPRES S.A. & IRS & NYSE & $1: 10$ & Real Estate & 1-May-94 \\
\hline METROGAS S.A. & MGS & NYSE & $1: 10$ & Oil \& Gas-Service & 26-Feb-01 \\
\hline PEREZ COMPANC & PC & NYSE & $1: 10$ & Util-Gas,Elec\&Water & 26-Jan-00 \\
\hline SIDERCA S.A.I.C & SDT & NYSE & $1: 10$ & Steel & 23-May-01 \\
\hline TELE ARG STET-FRANCE TELE & TEO & NYSE & 1:05 & Telecom-DatNtwk & 31-Mar-92 \\
\hline TELEFONICA DE ARGEN. & TAR & NYSE & $1: 10$ & Telecom-DatNtwking & 23-Dec-91 \\
\hline TRANSPORTADORA DE GAS DEL & TGS & NYSE & 1:05 & Oil \& Gas-Service & 17-Nov-94 \\
\hline YPF S.A. & YPF & NYSE & 1:01 & Oil \& Gas-Service & 1-Jun-93 \\
\hline \multicolumn{6}{|l|}{ Rule $144 \mathrm{~A}$ and OTC shares } \\
\hline BANCO HIPOTECARIO S.A. 144A & BHIPRR & PORTAL & 1:01 & Banking & 27-Jan-99 \\
\hline BANCO HIPOTECARIO S.A. REG S & -- & -- & 1:01 & Banking & 27-Jan-9 \\
\hline CAPEX S.A. GDR & CAPPP & PORTAL & 1:02 & Util-Gas,Elec\&Water & 23-Jun-94 \\
\hline CENTRAL COSTANERA S.A. & COSPP & PORTAL & $1: 10$ & Oil \& Gas-Service & 23-Dec-93 \\
\hline CENTRAL PUERTO, S.A. 144A & PUEPP & PORTAL & 1:05 & Oil \& Gas-Service & 1-Dec-93 \\
\hline MIRGOR S.A.C.I.F.I.A. - REG S & -- & -- & 1:01 & Auto-Auto Parts & 27-Oct-94 \\
\hline MIRGOR S.A.C.I.F.I.A. 144A & MIRPP & PORTAL & $1: 01$ & Auto-Auto Parts & 27-Oct-94 \\
\hline SIDERAR S.A.I.C. - REG S & -- & -- & $1: 08$ & Mining \& Minerals & 3-May-96 \\
\hline SIDERAR S.A.I.C. GDR & SDRPP & PORTAL & $1: 08$ & Mining \& Minerals & 3-May-96 \\
\hline SOCIEDAD COM DEL PLAT. & SCDPF & PORTAL & 1:01 & Fin Serv-Investment & 1-Aug-93 \\
\hline SOL PETROLEO S.A. & SLEOY & OTC & 1:01 & Oil \& Gas-Service & 1-Nov-9 \\
\hline
\end{tabular}

Source: Bank of New York 
Table 2 Price Impact of Corralito and Estimates of Expected Devaluation I. PERCENT CHANGE IN PRICE (IN \$US): WEEK BEFORE EVENT TO WEEK AFTER EVENT

$$
\text { CAVALLO }
$$

CORRALITO*

(A)
RESIGNATION** DEVALUATION

(B)

C

\section{EQUAL WEIGHTED PORTFOLIOS}

\section{ALL STOCKS}

2. ADRS

3. NON-ADRS

INDIVIDUAL ADRS

APSA
FRAN
CRES
GAL
IRSA
METRO
SIDERCA
TEL ARG
TGS
TECO
PC
YPF

\subsection{1}

7.58

2.52

0.00

9.58

2.98

3.83

$-1.63$

3.09

23.00

7.54

9.98

2.75

15.56

4.93

$\begin{aligned} 4.47 & \\ 7.45 & \\ 1.78 & \\ & \\ 0.00 & -46.17 \\ 12.36 & -48.98 \\ 6.31 & -35.80 \\ 11.02 & -46.60 \\ 11.39 & -42.70 \\ 30.52 & -44.83 \\ 19.72 & -40.28 \\ 0.00 & -32.98 \\ 20.35 & -44.53 \\ 32.35 & -40.36 \\ 30.26 & -44.60 \\ 10.58 & -39.91\end{aligned}$

II. AVERAGE DISCOUNT (LOCAL PRICE IN DOLLARS RELATIVE TO US PRICE)

$\begin{array}{ccccc} & \text { CORRALITO } & \text { CORRALITO } & \text { EXPECTED } & \text { EXPECTED } \\ \text { PRE-CORRALITO } & \text { PRE-DEVAL } & \text { POST-DEVAL } & \text { DEVAL } & \text { DEVAL }(2)^{* * *} \\ \text { (D) } & (\mathrm{E}) & (\mathrm{F}) & (\mathrm{G})=(\mathrm{E})-(\mathrm{F}) & (\mathrm{H})\end{array}$

(D)

(E)

(F)

(H)

\section{INDIVIDUAL ADRS}

$\begin{array}{lccc}\text { APSA } & & & \\ \text { FRAN } & -0.01 \% & 24.01 \% & 8.12 \% \\ \text { CRES } & 0.43 \% & 11.27 \% & 11.46 \% \\ \text { GAL } & 0.16 \% & 25.97 \% & 3.03 \% \\ \text { IRSA } & -0.13 \% & 16.96 \% & 7.54 \% \\ \text { METRO } & -3.45 \% & 9.14 \% & 5.31 \% \\ \text { SIDERCA } & -0.05 \% & 26.66 \% & 30.25 \% \\ \text { TEL ARG } & -0.81 \% & 12.73 \% & 8.60 \% \\ \text { TGS } & -0.10 \% & 26.63 \% & -0.56 \% \\ \text { TECO } & 0.00 \% & 24.24 \% & 47.63 \% \\ \text { PC } & -0.07 \% & 27.74 \% & 7.45 \% \\ \text { YPF } & 1.61 \% & 17.95 \% & 10.03 \% \\ & & \\ \text { Average } & & \\ \text { * } & & \\ \text { *pre-corralito week } 11 / 28 / 2001, \text { post-corralito week } 12 / 5 / 2001-12 / 7 / 2001 & \\ * * \text { pre-resignation week } 12 / 17 / 2001-12 / 19 / 2001 ; \text { post-resignation week } 12 / 20 / 2001 & -12 / 27 / 2001 \\ * * * \text { change between } 1 / 4 / 2002 \text { and } 1 / 11 / 2002 & \end{array}$


Table 3 Transaction Cost Ranges for ADR Conversions

\begin{tabular}{|c|c|c|c|}
\hline $\begin{array}{l}\text { Location } \\
\text { of } \\
\text { Trade or } \\
\text { Activity }\end{array}$ & Parameter & Description & $\begin{array}{l}\text { Estimated Range of Values } \\
\text { (percent of total value of } \\
\text { stock market transaction, } \\
\text { except where noted) }\end{array}$ \\
\hline \multirow[t]{2}{*}{$\begin{array}{l}\text { Buenos } \\
\text { Aires } \\
\text { Stock } \\
\text { Market }\end{array}$} & $\tau_{1}$ & $\begin{array}{l}\text { The brokerage fee is not regulated in } \\
\text { Argentina, but for market operations } \\
\text { larger than } 10,000 \text { pesos, the fee is in } \\
\text { the range }[0.25 \%, 1 \%] \text { of total } \\
\text { settlement, before Value Added Tax. } \\
\text { For amounts smaller than } 10,000 \text { the } \\
\text { fee is nonlinear, during December } \\
\text { most of the capital control- evading } \\
\text { transactions were settled for amounts } \\
\text { larger than } 10,000 \text { pesos. }\end{array}$ & {$[0.3025,1.21]$} \\
\hline & $\tau_{2}$ & $\begin{array}{l}\text { Fee that the Buenos Aires stock } \\
\text { exchange market charges for every } \\
\text { transaction. }\end{array}$ & 0.1025 \\
\hline $\begin{array}{l}\text { American } \\
\text { Depositary } \\
\text { Bank }\end{array}$ & $\tau_{4}$ & $\begin{array}{l}\text { ADR issuance (conversion) fee } \\
\text { charged by the broker, (this is a } \\
\text { markup over the conversion fees } \\
\text { charged by depositary banks.) }\end{array}$ & [0.10 dollar, 0.20 dollars] \\
\hline \multirow{2}{*}{$\begin{array}{l}\text { NYSE } \\
\text { Stock } \\
\text { Market }\end{array}$} & $\tau_{3}$ & $\begin{array}{l}\text { Argentinean brokers selling the ADR } \\
\text { in the US are charged the same fee as } \\
\text { they are when buying or selling stocks } \\
\text { in the local market. }\end{array}$ & {$[0.3025,1.21]$} \\
\hline & $\tau_{5}$ & $\begin{array}{c}\text { Approximate cost of opening a } \\
\text { banking account in the US and wire } \\
\text { transferring the foreign currency to a } \\
\text { US bank. }\end{array}$ & 1 \\
\hline
\end{tabular}

\begin{tabular}{|c|l|c|c|}
\hline $\begin{array}{c}\text { Argentinean } \\
\text { Bank }\end{array}$ & $\tau_{6}$ & $\begin{array}{c}\text { Approximate cost of transferring } \\
\text { money from Argentina to the US. } \\
\text { During the capital controls period } \\
\text { these transactions were not allowed. }\end{array}$ & 1 \\
\hline
\end{tabular}

Source: invertironline.com and portfoliopersonal.com 
Table 4 Explaining Argentine Stock (with associated ADRs) portfolio returns in Argentina Using a Global Market Portfolio and an Argentine (Non-ADR) Market Portfolio

\begin{tabular}{|c|c|c|c|c|c|c|}
\hline TIME PERIOD & $\begin{array}{l}\text { Global } \\
\text { Market } \\
\text { Index }\end{array}$ & & $\begin{array}{l}\text { Local } \\
\text { Market } \\
\text { Index }\end{array}$ & & & \\
\hline & $\beta_{1}$ & t-stat & $\beta_{2}$ & t-stat & $\mathrm{R}^{2}$ & Obs \\
\hline Pre-corralito & 0.417 & 8.426 & 0.832 & 21.684 & 0.45 & 1038 \\
\hline \multicolumn{7}{|l|}{ Post-corralito } \\
\hline Dec ’01 - Feb '02 & 0.477 & 0.939 & 1.459 & 7.469 & 0.69 & 48 \\
\hline Jan - Mar '02 & 0.338 & 0.789 & 1.224 & 8.552 & 0.86 & 52 \\
\hline Feb - Apr '02 & 0.269 & 0.879 & 1.026 & 6.599 & 0.87 & 53 \\
\hline Mar-May '02 & 0.68 & 1.661 & 0.909 & 3.673 & 0.7 & 57 \\
\hline
\end{tabular}

Note: The global market index is the MSCI world index return and the local market index is an orthgonalized equal-weighted portfolio (in dollars) of all the stocks traded in Buenos Aires except those with an associated ADR. The dependent variable is the return in Argentina of an equal-weighted portfolio of the 12 stocks with associated ADRs. Data source: Economatica.

Table 5 Explaining ADR Portfolio Returns in New York Using A Global Market Portfolio and an Argentine (Non-ADR) Market Portfolio

\begin{tabular}{|r|r|r|r|r|r|r|}
\hline Time Period & \multicolumn{1}{|c|}{$\begin{array}{c}\text { Global } \\
\text { Market } \\
\text { Index }\end{array}$} & & \multicolumn{1}{c|}{$\begin{array}{c}\text { Local } \\
\text { Market } \\
\text { Index }\end{array}$} & & & \\
\hline & $\beta 1$ & $\mathrm{t}$-stat & $\beta_{2}$ & $\mathrm{t}$-stat & $\mathrm{R}^{2}$ & \multicolumn{1}{c|}{ Obs } \\
\hline Pre-corralito & 0.616 & 12.44 & 0.883 & 22.78 & 0.55 & 1054 \\
\hline Post-corralito & & & & & & \\
\hline Dec '01 - Feb '02 & 0.336 & 1.176 & 0.057 & 1.322 & 0.06 & 61 \\
\hline Jan - Mar'02 & 0.596 & 1.945 & 0.084 & 2.304 & 0.17 & 61 \\
\hline Feb - Apr'02 & 0.496 & 1.992 & 0.168 & 3.748 & 0.27 & 62 \\
\hline Mar - May '02 & 0.733 & 3.648 & 0.128 & 3.287 & 0.35 & 64 \\
\hline
\end{tabular}

Note: The global market index is the MSCI world index return and the local market index is an orthgonalized equal-weighted portfolio (in dollars) of all the stocks traded in Buenos Aires except those with an associated ADR. The dependent variable is the return in New York of an equal-weighted portfolio of the 12 ADR stocks. Data source: Economatica 
Figure 1 Emerging Markets' Stock Market Response During Currency Crises 60-day window centered on the corresponding devaluation date (Dollar Stock Market Indices; Base $=100$ on the day of the devaluation)

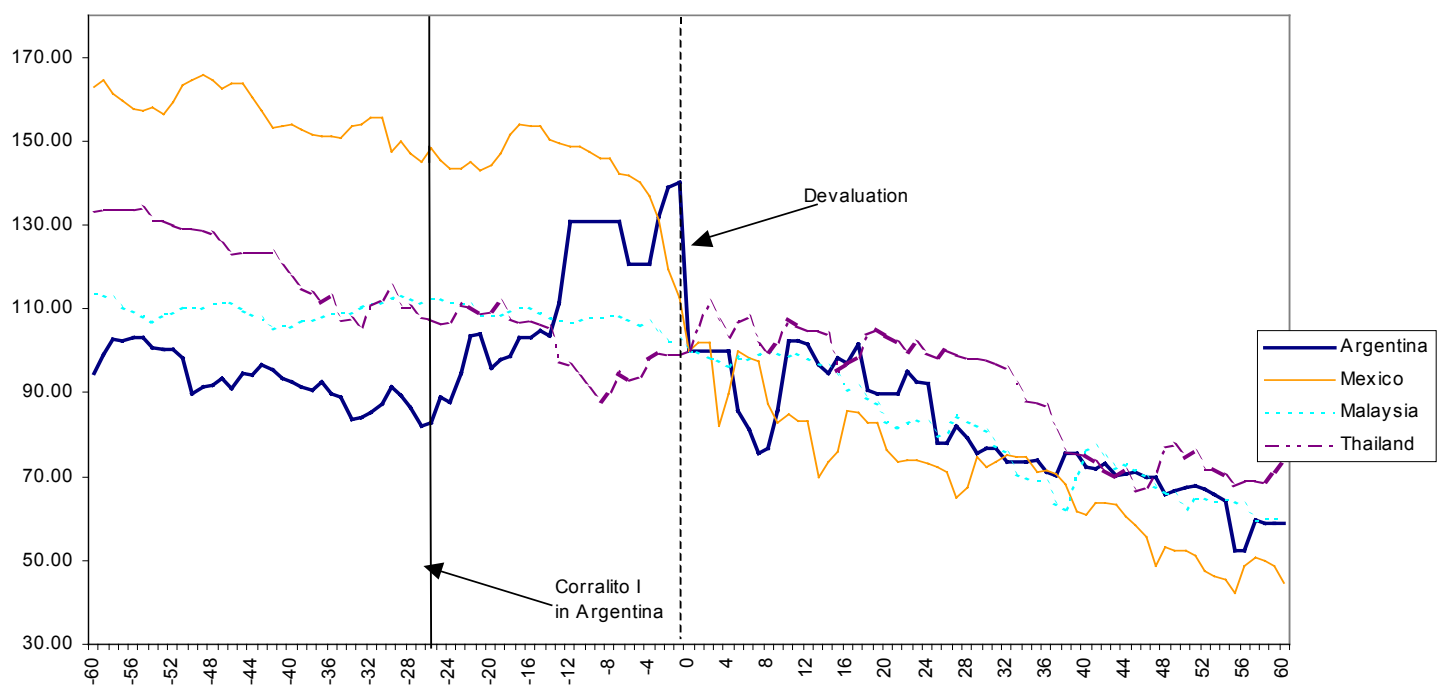

Source: Datastream

Figure 2 Argentine Merval Index (January 1990-June 2002)

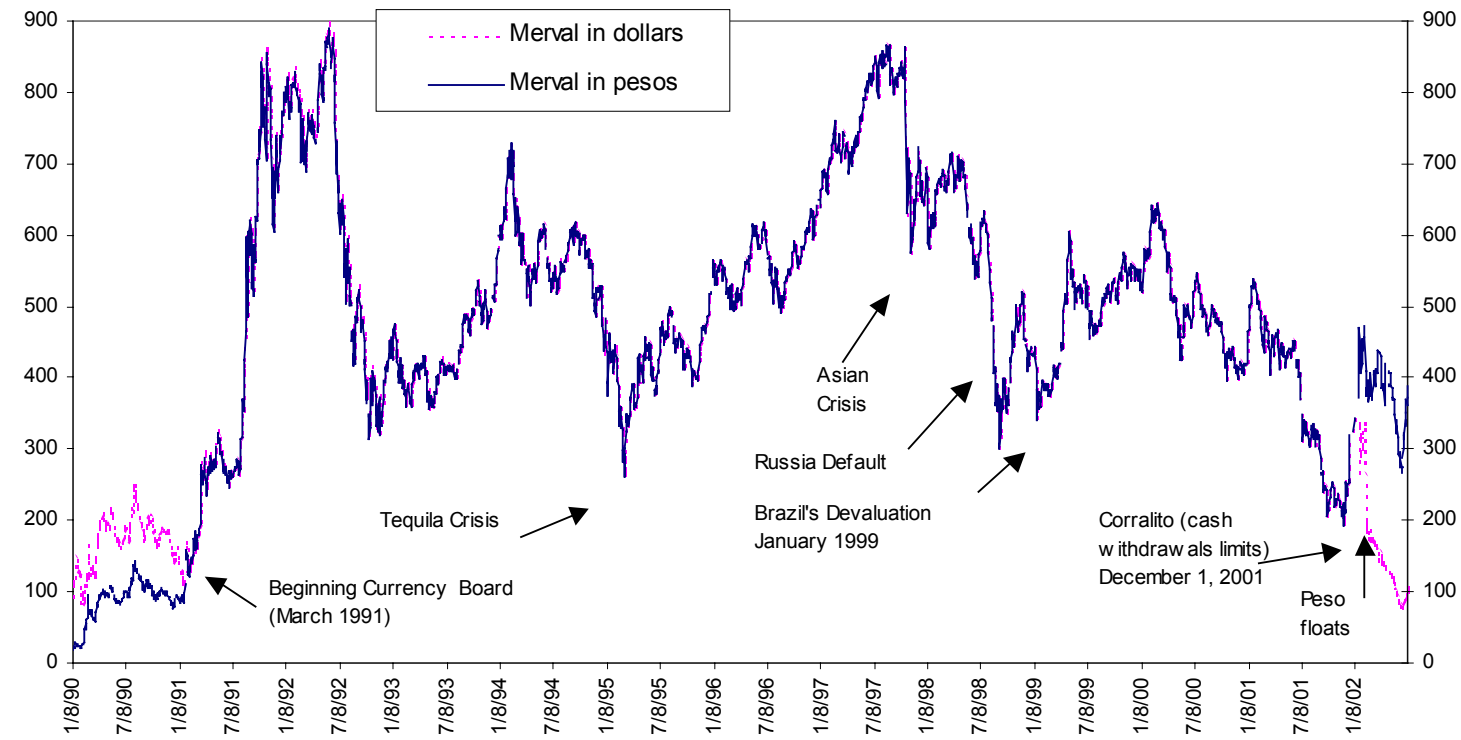

Source: Datastream 
Figure 3 Equal-Weighted Portfolios of ADR and Non-ADR Stocks (July 2001 - May 2002; December 2001=100)

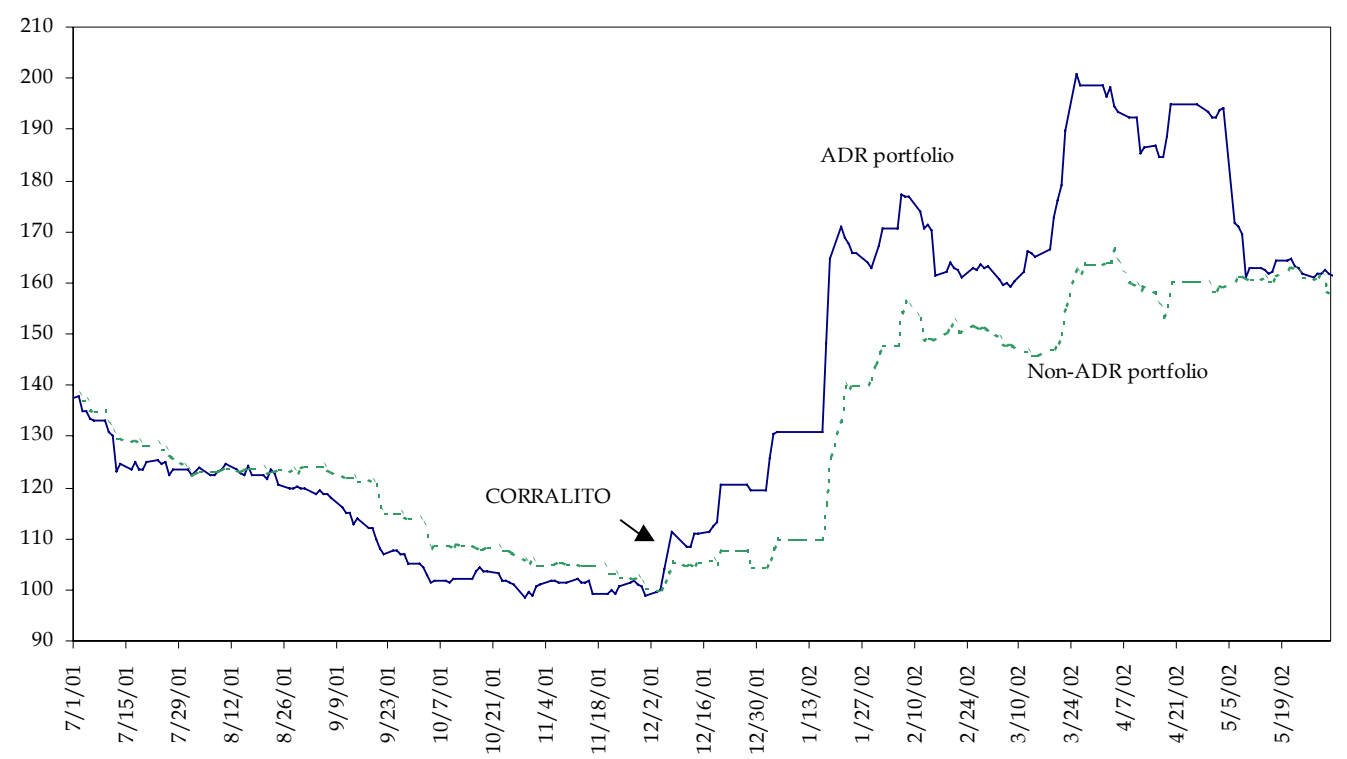

Source: Datastream

Figure 4 Number of Shares Traded and Dollar Volume of Argentine Stocks

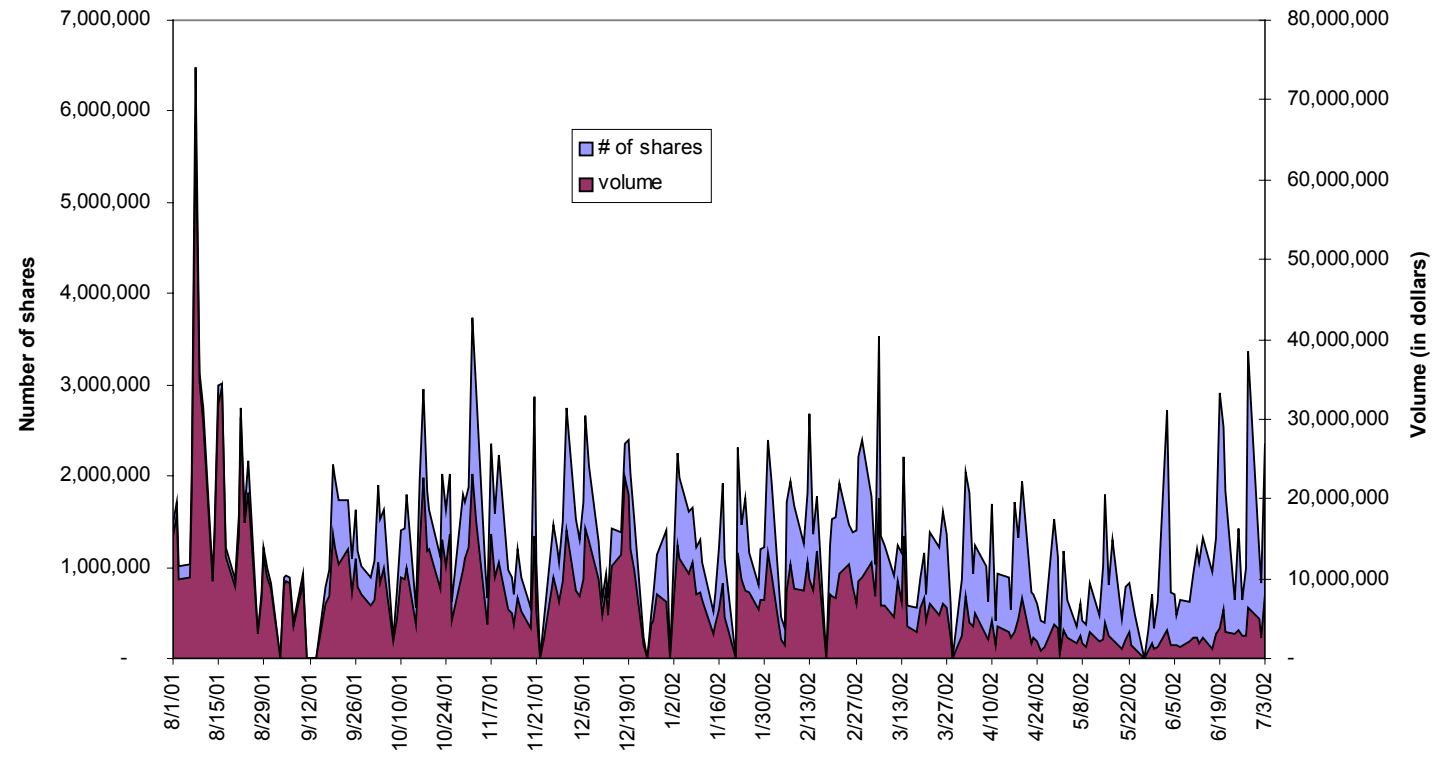


Figure 5 Trading Volume in ADRS as a percent of Total Trading Volume

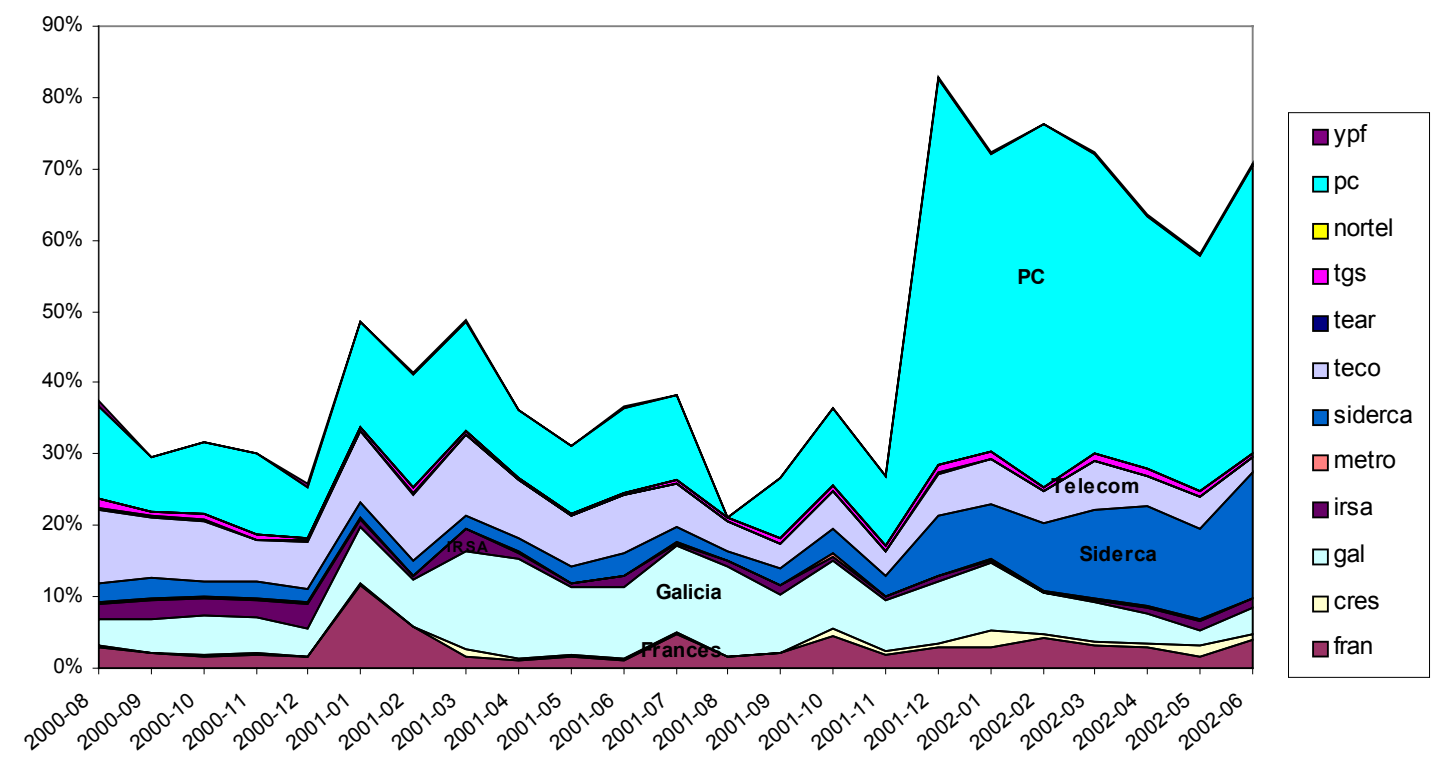

Source: Bloomberg 
Figure 6 Argentine and U.S. Prices and Premia for Perez Companc (U.S. Dollars)

LOCAL AND US PRICE IN \$US: PEREZ COMPANC

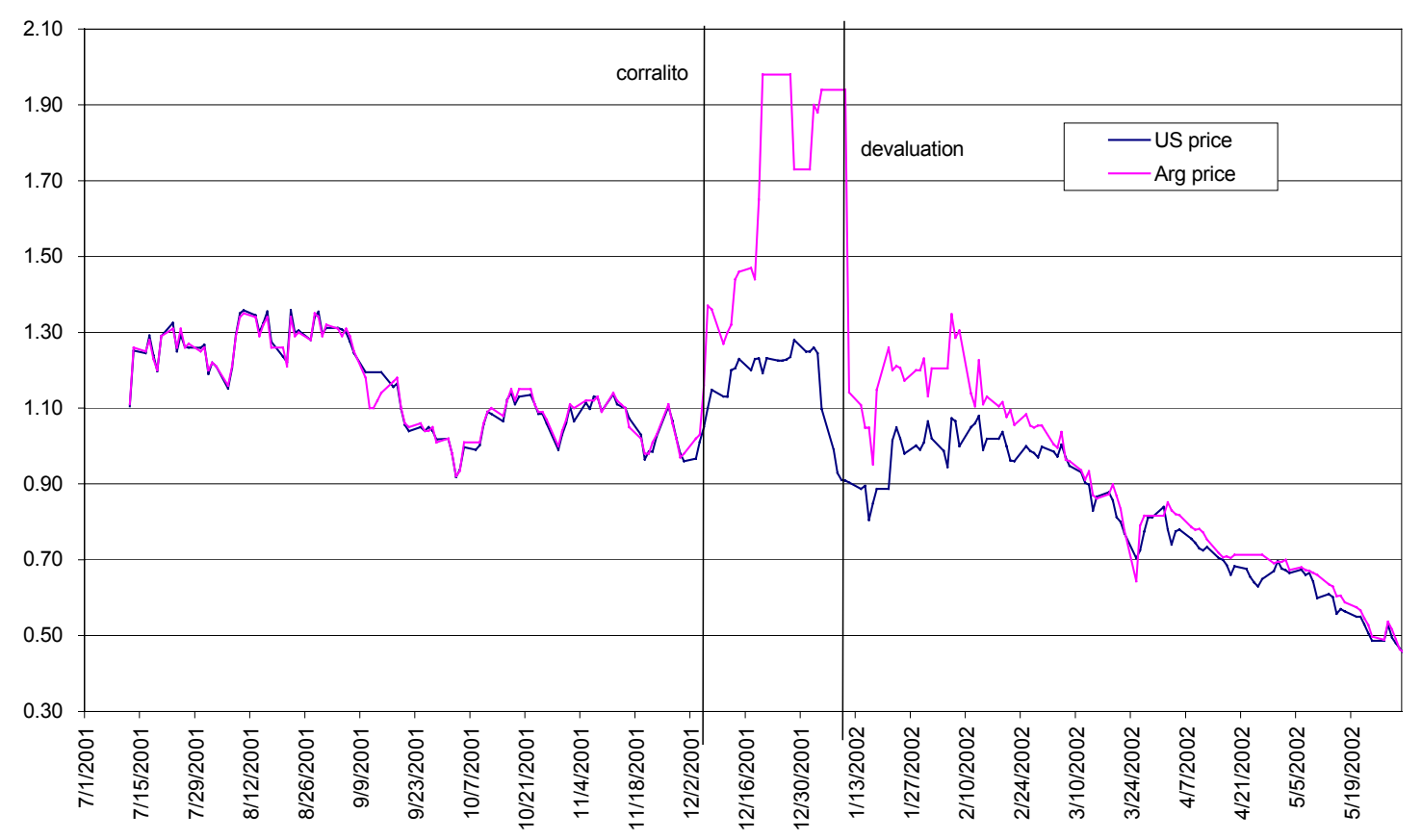

DISCOUNT AND ARBITRAGE BOUNDS: PEREZ COMPANC

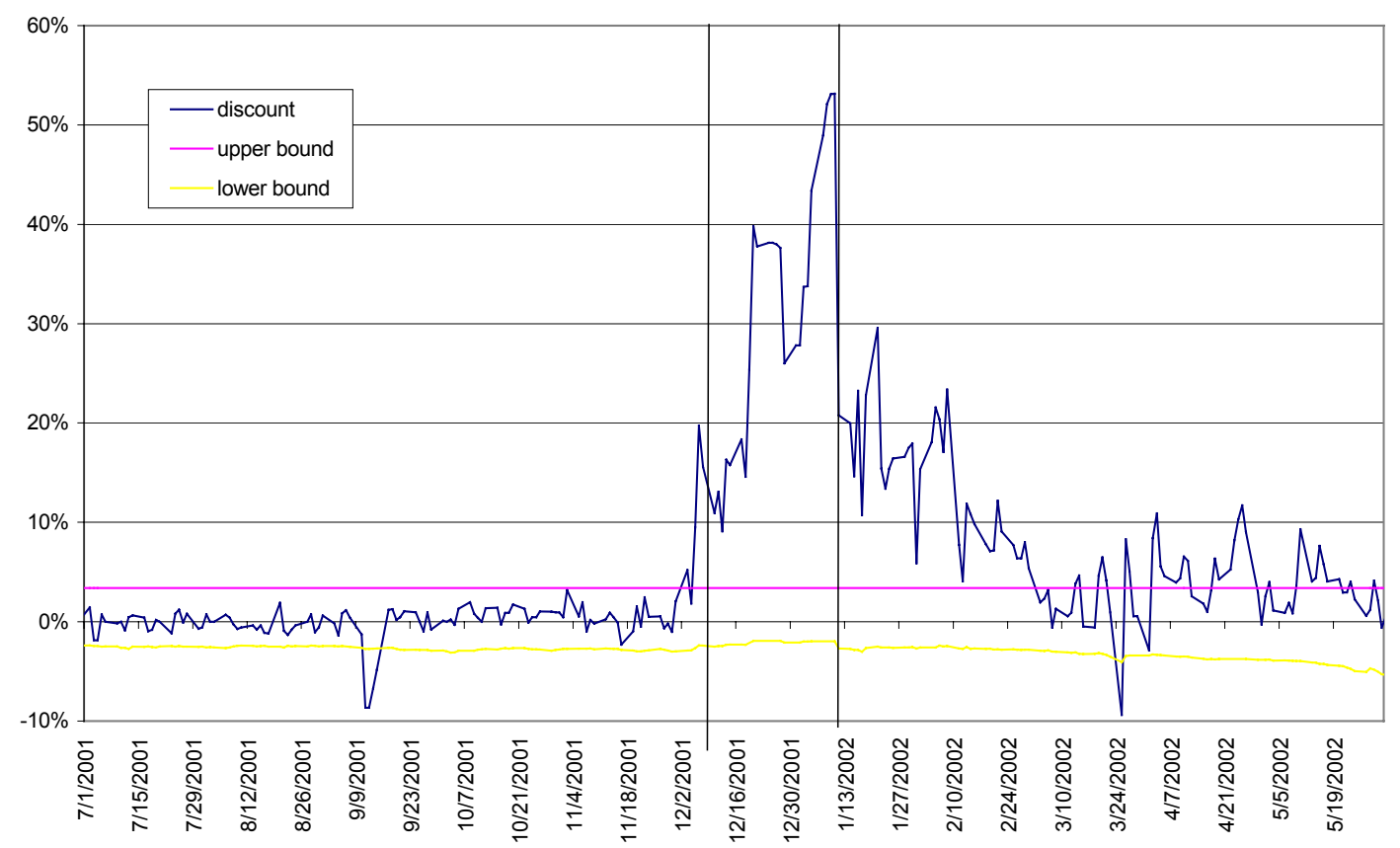


Figure 7 Argentine and U.S. Prices and Premia for Siderca (U.S. Dollars)

LOCAL AND US PRICE IN \$US: SIDERCA

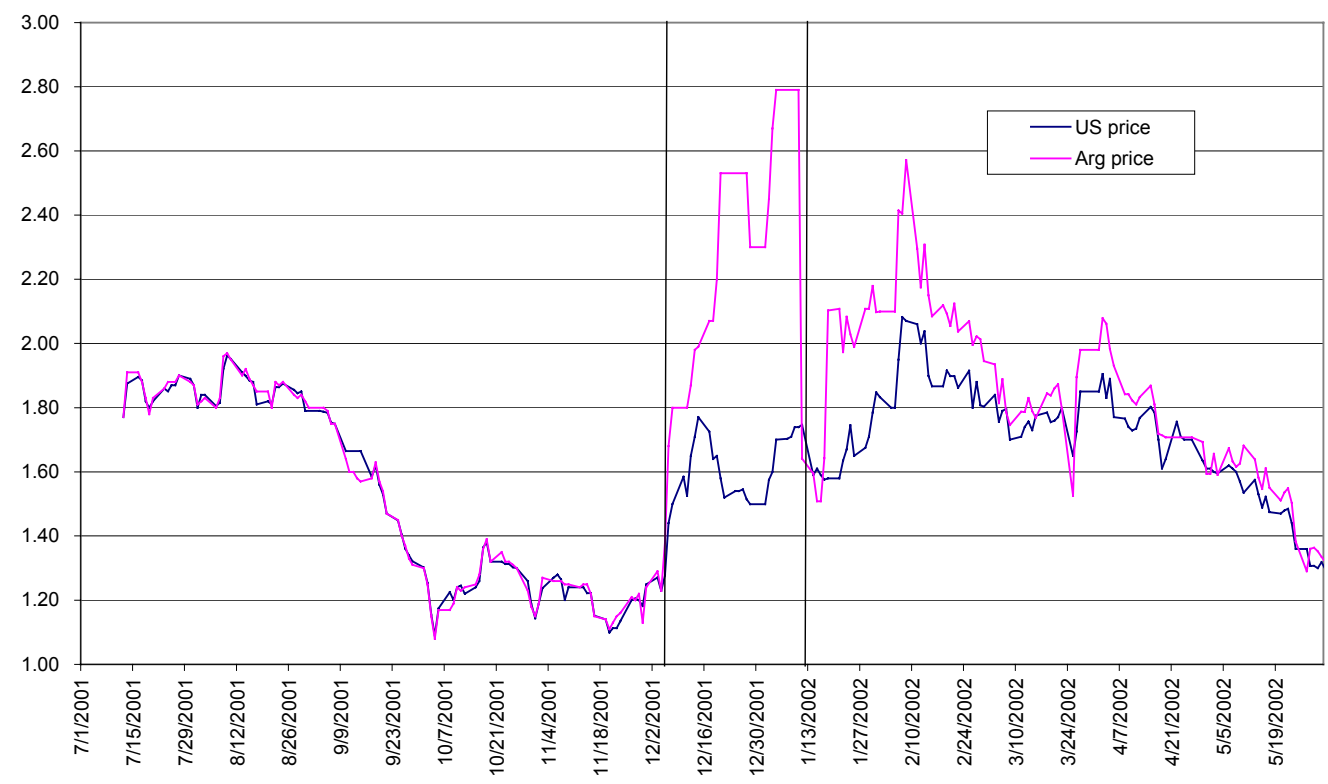

DISCOUNT AND ARBITRAGE BOUNDS: SIDERCA

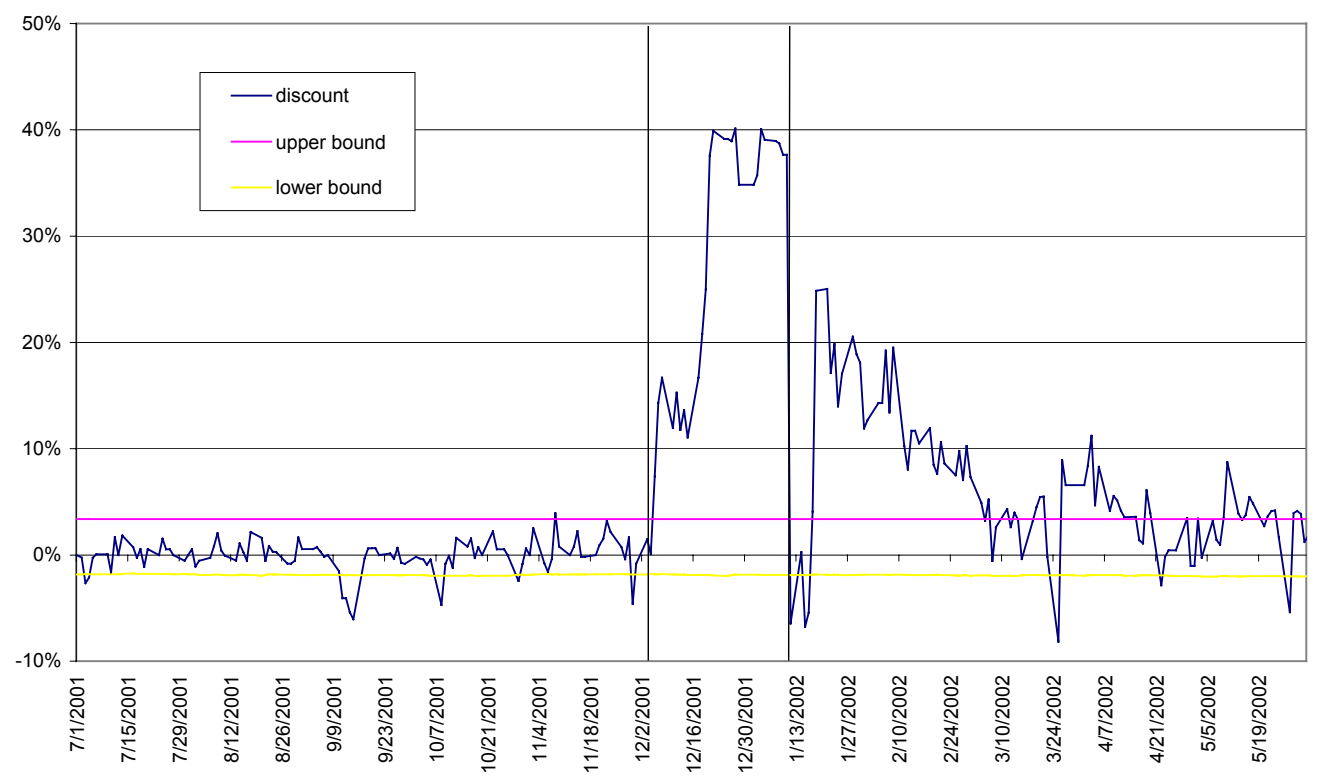


Appendix 1

Argentina's Financial Market Event Time Line

\begin{tabular}{|c|c|}
\hline October 28, 2001 & $\begin{array}{l}\text { Minister Cavallo starts negotiations with the IMF and the U.S. } \\
\text { Treasury to purchase collateral for new bonds to be issued in an } \\
\text { exchange for the nearly } \$ 100 \text { billion of local and external debt. }\end{array}$ \\
\hline October 29, 2001 & $\begin{array}{l}\text { Mr. Cavallo defines the debt exchange operation as voluntary. } \\
\text { The old debt would exchange for bonds paying seven percent } \\
\text { per year and be guaranteed by tax revenues. The IMF and U.S. } \\
\text { Treasury ask for compliance with a zero deficit and an } \\
\text { agreement with the provinces on tax revenue sharing before } \\
\text { any kind of financial support is given. }\end{array}$ \\
\hline November 19, 2001 & $\begin{array}{l}\text { The IMF announces it will not make any new disbursements } \\
\text { (around 1.3 billion dollars) without being satisfied that the } \\
\text { country has secured the goals previously designated. }\end{array}$ \\
\hline November 30, 2001 & $\begin{array}{l}\text { End of a debt swap with local banks and pension funds for } \\
\text { more that } 55 \text { billion (over a total public debt of } 160 \text { billions). }\end{array}$ \\
\hline December 2, 2001 & $\begin{array}{l}\text { The government announces cash withdrawal limits (Corralito) } \\
\text { and limits dollar transfers abroad as a last-ditch effort to fend } \\
\text { off a devaluation and prevent a major banking crisis. } \\
\text { Withdrawals are limited to } 250 \text { pesos (dollars) per week per } \\
\text { account. Depositors, however, may still access their funds for } \\
\text { larger purchases through checks or debit cards and transfer } \\
\text { their money among banks. No limits are placed on domestic } \\
\text { payments through the use of checks, credits, debit cards and } \\
\text { electronic MEP (Metodo Electronico de Pagos) payments. } \\
\text { Initially the government stated that the Corralito would last } 3 \\
\text { months. }\end{array}$ \\
\hline December 3, 2001 & $\begin{array}{l}\text { The measures announced on Dec } 2 \text { nd come into full effect } \\
\text { through Decree } 1570-01 \text { on Dec } 3 \text { rd. They can be summarized } \\
\text { as follows: } \\
\text { a) Wire transfers are not allowed without prior Central Bank } \\
\text { approval. } \\
\text { b) Cash withdrawals from the Banking System will be limited } \\
\text { to US\$ } 1000 \text { per month. } \\
\text { c) Financial Argentine institutions may not participate in } \\
\text { foreign currency futures transactions. } \\
\text { d) Financial Argentine institutions are prohibited from issuing } \\
\text { new bank loans denominated in Argentine Pesos. All new loans } \\
\text { must be issued in U.S. dollars and existing peso loans must be } \\
\text { converted to U.S. dollar loans at a one to one rate. } \\
\text { e) Foreign investors trading in the Argentine Securities Market } \\
\text { are subject to the repatriation restriction. Funds related to } \\
\text { securities transactions must remain in the country until } \\
\text { government approval is obtained or the measure is officially } \\
\text { revoked. }\end{array}$ \\
\hline
\end{tabular}




\begin{tabular}{|c|c|}
\hline December 4, 2001 & $\begin{array}{l}\text { The Merval Index (Buenos Aires Stock Exchange) increases } \\
6 \% \text {. According to the local press, there was incipient trading in } \\
\text { ADRs. }\end{array}$ \\
\hline December 7, 2001 & $\begin{array}{l}\text { Following Decree 1570, the Central Bank established an } \\
\text { information procedure for the processing of automatic and non- } \\
\text { automatic authorizations of repatriation. According to this rule, } \\
\text { coupon payments on National Government Bonds have } \\
\text { automatic transfer authorization and all other types of payments } \\
\text { and repatriations of U.S. dollars are subject to Central Bank } \\
\text { approval. }\end{array}$ \\
\hline December 19, 2001 & Mr. Cavallo and all other ministers resign. \\
\hline December 20, 2001 & $\begin{array}{l}\text { President Dela Rua resigns and Mr. Ramon Puerta becomes } \\
\text { interim president. Country Risk reaches } 4618 \text { points. Global } \\
\text { (sovereign) bond yields reach their historical maximum of } 49 \% \\
\text { annual return in dollars. }\end{array}$ \\
\hline December 21, 2001 & $\begin{array}{l}\text { The official Foreign Exchange Rate market is closed until the } \\
10^{\text {th }} \text { of January, } 2002 .\end{array}$ \\
\hline December 23, 2001 & $\begin{array}{l}\text { Mr. Rodriguez Saa, governor of one of the provinces, becomes } \\
\text { the new interim president for } 60 \text { days, until elections are called } \\
\text { in March, } 2002 \text {. He declares the suspension of external debt } \\
\text { payments for at least } 60 \text { days, totaling } \$ 166 \text { bn in federal and } \\
\text { provincial debt. }\end{array}$ \\
\hline December 24, 2001 & $\begin{array}{l}\text { The government announces that a new fiat currency (i.e., } \\
\text { without foreign-currency backing) would be created (the } \\
\text { argentino). }\end{array}$ \\
\hline December 30, 2001 & $\begin{array}{l}\text { Interim president Mr. Rodriguez Saa resigns and the legislative } \\
\text { assembly elects Mr. Eduardo Duhalde as new president. }\end{array}$ \\
\hline December 31, 2001 & $\begin{array}{l}\text { In the midst of political instability and closed foreign exchange } \\
\text { markets, the peso trades on the black market at } 1.35 \text { pesos per } \\
\text { dollar. }\end{array}$ \\
\hline January 2,2002 & Mr. Duhalde assumes power. \\
\hline January 7, 2002 & $\begin{array}{l}\text { The new Minister of Finance, Mr. Lenicov, announces the } \\
\text { devaluation of the peso and a new dual foreign exchange rate } \\
\text { regime, to be implemented on the } 9^{\text {th }} \text { of January, } 2002 \text {. }\end{array}$ \\
\hline
\end{tabular}




\begin{tabular}{|c|c|}
\hline January 11, 2002 & $\begin{array}{l}\text { After several delays, the exchange rate market re-opens and the } \\
\text { new dual exchange rate system is put in place, under the } \\
\text { "Public Emergency and Exchange Regulations" approved by } \\
\text { Congress. The main articles and measures are the following: } \\
\text { a) } 1 \text { Argentinean peso= } 1 \text { U.S. dollar parity (Convertibility } \\
\text { Plan) is abolished. For emergency reasons, the Executive } \\
\text { Power- President- has been authorized to determine both the } \\
\text { new official rate of exchange between the Argentinean peso } \\
\text { and foreign currency and exchange rate regulations. } \\
\text { b) All debts (capital and interests) agreed in ARG currency } \\
\text { with financial entities - converted into U.S. dollars according to } \\
\text { the Decree } 1570 / 2001 \text { - will be reconverted into the original } \\
\text { currency agreed (pesos). } \\
\text { c) The official, fixed conversion rate - } 1 \text { U.S Dollar=1.4 pesos } \\
\text { will be relevant for foreign trade operations. The free or } \\
\text { floating rate will be used for all other transactions and freely } \\
\text { determined by the market. } \\
\text { The peso was quoted at } 1.8 \text { per dollar at money-changers in } \\
\text { Buenos Aires. The peso's decline was limited by the } \\
\text { government's decision to reduce the amount of money in } \\
\text { circulation through a freeze on deposits, withdrawal restrictions } \\
\text { and a central bank order blocking banks from selling the U.S. } \\
\text { currency via electronic transactions. }\end{array}$ \\
\hline January 21,2002 & $\begin{array}{l}\text { The government announces the easing of bank withdrawal } \\
\text { restrictions: } \\
\text { a) Up to } 7,000 \text { pesos can be withdrawn from term deposits in } \\
\text { pesos (transferring that money to a checking account) } \\
\text { b) Up to 5,000 dollars can be withdrawn from term deposits in } \\
\text { dollars (transferring that money to a checking account at the } \\
\text { official exchange rate, 1.40). } \\
\text { c) Up to 5,000 dollars in a saving account can be pesofied at } \\
\text { the official exchange rate. }\end{array}$ \\
\hline February 3, 2002 & $\begin{array}{l}\text { Mr. Lenicov announces an asymmetric pesofication and the end } \\
\text { of the dual exchange rate regime. The fundamental economic } \\
\text { measures were the following: } \\
\text { a) pesofication of all dollar deposits at } 1.4 \text { pesos per dollar. } \\
\text { b) corporate and consumer debts are also pesofied, but at the } \\
\text { exchange rate prevailing during the Convertibility period. Both } \\
\text { deposits and credit will be indexed to inflation. } \\
\text { c) the end of the dual exchange rate regime and a unified } \\
\text { floating exchange rate determined by market forces. } \\
\text { d) the right to withdraw wage and pension income from the } \\
\text { corralito without any amount restrictions (before workers could } \\
\text { only extract up to } 1.500 \text { pesos). }\end{array}$ \\
\hline
\end{tabular}




\begin{tabular}{|c|c|}
\hline February 4, 2002 & $\begin{array}{l}\text { The official foreign exchange market is closed again until the } \\
11^{\text {th }} \text { of February. }\end{array}$ \\
\hline February 8, 2002 & $\begin{array}{l}\text { While the foreign exchange market is closed and before } \\
\text { devaluation uncertainty is resolved, the stock market index } \\
\text { increases. The pesification of all debts announced in Argentina } \\
\text { drives up share prices of firms heavily indebted in pesos and } \\
\text { banks. } \\
\text { The mix of announced policy measures not yet implemented, } \\
\text { (including the pesification of all debts and the prospects of a } \\
\text { large devaluation once the market re-opened) and the non- } \\
\text { operation of the exchange rate market, induce some investors to } \\
\text { reverse the capital-outflow process, converting ADRs back into } \\
\text { underlying shares and selling them in the Argentinean market. } \\
\text { The implicit dollar rate obtained through this operation was } \\
2.56 \text { pesos (above the } 2.35 \text { pesos in the black market) and } \\
\text { allowed the repayment of pesofied corporate debt. }\end{array}$ \\
\hline February 11, 2002 & $\begin{array}{l}\text { The BCRA establishes a new unified free foreign exchange } \\
\text { market, which replaces the two markets - official and free - } \\
\text { implemented in January. The exchange rate market re-opens } \\
\text { and the floating dollar exchange rate reaches } 2.1 \text { pesos, well } \\
\text { below the devaluation expectations built-into asset prices. }\end{array}$ \\
\hline February 12, 2002 & $\begin{array}{l}\text { The stock market drops an accumulated } 18 \% \text { in the two } \\
\text { business days following the launching of the new exchange rate } \\
\text { regime. }\end{array}$ \\
\hline March 26, 2002 & $\begin{array}{l}\text { The Central Bank announces new measures related to foreign } \\
\text { exchange transactions and ADR/CEDEAR conversions. } \\
\text { According to the press release, these were aimed at improving } \\
\text { the functioning of the foreign currency market and regulating } \\
\text { the buying and selling of foreign currency by order and for the } \\
\text { account of the Central Bank. } \\
\text { The press communication also mentions that there will be } \\
\text { coordination between the Comision Nacional de Valores } \\
\text { (CNV) - the equivalent to the SEC in the U.S. - and the Bolsa } \\
\text { de Comercio de Buenos Aires (BCBA) - the Buenos Aires } \\
\text { Stock Exchange - in order to adopt new measures to regulate } \\
\text { capital outflows via ADR and CEDEAR transactions. } \\
\text { However, neither the CNV nor the BCBA have yet issued any } \\
\text { official communication regulating these transactions. }\end{array}$ \\
\hline
\end{tabular}

Sources: Ambito Financiero, La Nacion and Clarin (various issues) and Pictet. 
Appendix 2

Argentine Exchange Rate Market Developments

FOREIGN EXCHANGE MARKET REGIMES IN ARGENTINA

Daily Exchange Rate in Pesos per Dollar: December 3rd 2001 - 31st of May 2002

(solid black line denotes period when official market was closed)

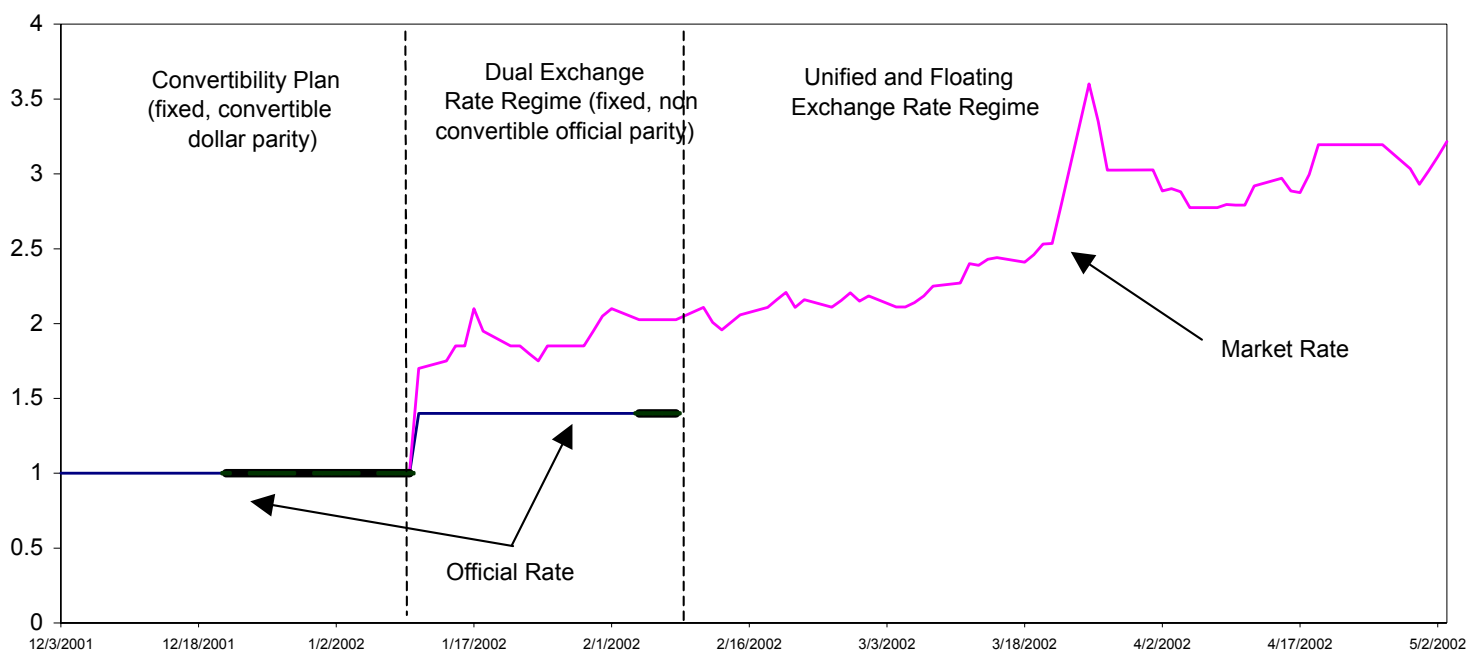

The Argentine foreign exchange rate market was closed (feriado cambiario) from the $21^{\text {st }}$ of December until the $10^{\text {th }}$ of January (inclusive). During this period the shadow (or parallel) market exchange rate quoted at around 1.5-1.6 pesos per dollar, well above the official parity of 1 peso per dollar prevailing before markets were closed.

On January $4^{\text {th }}$ the Minister of Finance announced the discontinuation of the currency board and on January 7 th, the Minister of Finance announced the devaluation of the peso and a new exchange rate regime. The new exchange rate regime was a dual one, featuring an official, fixed non-convertible rate of 1.4 pesos per dollar (relevant for exporters and financial institutions) and a free or floating dollar, for all other operations and determined by supply and demand. This new dual regime came into full effect on Friday the $11^{\text {th }}$ of January when the markets were re-opened.

On January the $11^{\text {th }}$ there were two different values for the free exchange rate: dollars purchased with cash at 1.7-1.8 "free pesos" per dollar, and a higher exchange rate for dollars purchased with checks from funds in the Corralito (1.9-2 "trapped pesos" per dollar).

Exchange rate market operations were again suspended from the $4^{\text {th }}$ of February to the 8 th $^{\text {th }}$ of February, inclusive. On Sunday, February $3^{\text {rd }}$, the new Minister of Finance announced the end of the dual exchange rate regime and a unified floating exchange rate was put in place on Monday, February $11^{\text {th }}$. On the $11^{\text {th }}$, the floating exchange rate opened at 2.10 pesos per dollar. 